\title{
The growth response of rice (Oryza sativa L. var. FARO 44) in vitro after inoculation with bacterial isolates from a typical ferruginous ultisol
}

\author{
Musa Saheed Ibrahim ${ }^{1,2^{*}}$ (D) and Beckley Ikhajiagbe ${ }^{2}$
}

\begin{abstract}
Background: Rice forms a significant portion of food consumed in most household worldwide. Rice production has been hampered by soil factors such as ferruginousity which has limited phosphorus availability; an important mineral component for the growth and yield of rice. The presence of phosphate-solubilizing bacteria (PSB) in soils has been reported to enhance phosphate availability. In view of this, the present study employed three bacteria species (BCAC2, EMBF2 and BCAF1) that were previously isolated and proved P solubilization capacities as inocula to investigate the growth response of rice germinants in an in vitro setup. The bacteria isolates were first identified using $16 \mathrm{~S}$ rRNA gene sequencing and then applied as inoculum. The inolula were prepared in three concentrations (10, 7.5 and $5.0 \mathrm{ml}$ ) following McFarland standard. Viable rice (var. FARO 44) seeds were sown in petri dishes and then inoculated with the three inocula at the different concentrations. The setup was studied for 28 days.
\end{abstract}

Results: $16 \mathrm{~S}$ rRNA gene sequencing identified the isolates as: isolate BCAC2= Bacillus cereus strain GGBSU-1, isolate $\mathrm{BCAF} 1=$ Proteus mirabilis strain TL14-1 and isolate $\mathrm{EMBF} 2=$ Klebsiella variicola strain AUH-KAM-9. Significant improvement in rice germination, morphology, physiology and biomass parameters in the bacteria-inoculated setups was observed compared to the control. Germination percentage after 4 days was $100 \%$ in the inoculated rice germinants compared to $65 \%$ in the control (NiS). Similarly, inoculation with the test isolates enhanced water-use efficiency by over $40 \%$. The rice seedlings inoculated with Bacillus cereus strain GGBSU-1 (BiS) showed no signs of chlorosis and necrosis throughout the study period as against those inoculated with Proteus mirabilis strain TL14-1 (PiS) and Klebsiella variicola strain AUH-KAM-9 (KiS). Significant increase in chlorophyll-a, chlorophyll-b and alpha amylase was observed in the rice seedlings inoculated with BiS as against the NiS.

Conclusion: Inoculating rice seeds with Bacillus cereus strain GGBSU-1, Proteus mirabilis strain TL14-1 and Klebsiella variicola strain AUH-KAM-9 in an in vitro media significantly improved growth parameters of the test plant. Bacillus cereus strain GGBSU-1 showed higher efficiency due to a more improved growth properties observed.

Keywords: Growth response, Phosphate-solubilizing bacteria, Plant growth-promoting capabilities, FARO 44

\footnotetext{
*Correspondence: Musasa39id@gmail.com

1 Department of Biological Sciences, Admiralty University of Nigeria,

Ibusa, Delta State, Nigeria

Full list of author information is available at the end of the article
}

\section{Background}

Before year 2050, agricultural production must increase by $70 \%$ in order to meet up with the ever-increasing world population and food demand. However, arable lands will only increase by $6 \%$ by 2050 (Alexandratos and Bruinsma 2012). Currently, in developing countries, 
larger percentage of arable land is facing poor biotic and abiotic factors which have consequently affected soil fertility (Beatrice et al. 2018). Cultivation of crops, such as maize and rice, has been hampered by these soil factors including high $\mathrm{pH}$, low soil nitrogen and phosphorus deficiency (Adnan et al. 2018; Joshis et al. 2007). The combination of these poor soil conditions is found in ferruginous soils (Cho and Ponnamperuma 1971). Considering the state of rice as the most consumed food in Africa (Ajala and Gana 2015; Shiferaw et al. 2011), there is a need to improve rice cultivation to meet up with the ever-increasing population (FAOSTAT 2020).

Rice (Oryza sativa L.) is an edible starchy cereal grain consumed by more than $50 \%$ of the world population (Maclean et al. 2002). It is the most consumed food in Africa (Ajala and Gana 2015) because it has the potentials of improving nutrition, boost food security and foster rural development (Ojo and Adebayo 2012). Rice provides more than $20 \%$ of the total calories consumed by human universally (Udemezue 2018) and 15\% of the protein requirements of human beings (Kennedy et al. 2002). In Nigeria, it has become an important strategic and daily staple food crop. It is mostly cultivated in the northern States such as Kano and least cultivated in southern states such as Edo State (Daramola 2005; Obayelu 2015). Rice cultivation is highly nutrient demanding, soil nutrient depletion, loss of soil organic matter (Nye and Greenland 1961), excessive soil tillage, low soil nitrogen, phosphorus deficiency and iron toxicity, which are considered major hindrances for rice crops (Adnan et al. 2018; Joshis et al. 2007). Linking these hindrances with other reasons may be the reason why some southern states in Nigeria such as Edo is experiencing low rice production.

Ferruginous soils that cover approximately 64 million $\mathrm{km}^{2}$ and accounted for $45.2 \%$ of the Earth's surface area have been considered as a major hindrance for rice farming (Anumalla et al. 2019). In Nigeria for example, it is predominant in some southern States such as Edo state, occupying about seven zones, including extreme north and central Benin (Doyou et al. 2017). These soils are being known for their high iron content, low bioavailable phosphate, diminished nitrogen, low organic matter and poor water retention capacity (Wang et al. 2014). The high iron in ferruginous soils forms complexes with soil insoluble phosphate, therefore limiting the bioavailable phosphorus for plants (Gyaneshwar et al. 2002). These soil properties impair plant growth and development. In a bid to improve soil fertility, modern farmers have employed the use of synthetic phosphate fertilizers that had negatively compounded the fertility problem faced by the soil and caused crop damage and food insecurity as a result of deficiency in beneficial soil microorganisms that can solubilize and mineralize the insoluble phosphate and make it bioavailable for plants (Sharma et al. 2013). Therefore, given the negative environmental and agricultural impact of synthetic phosphate fertilizers and their increasing cost, the use of beneficial soil microorganisms such as plant growth-promoting rhizobacteria (PGPR) has increased globally during the last couple of decades (Ikhajiagbe and Edokpolo 2019; Ivy et al. 2018; Balayogan and Marimuthu 2014). For example, Saneya and Muhammad (2017) observed a 75\% increase in the growth of Chili when inoculated with PGPR compared to synthetic fertilizers. However, for phosphate deficient soils, there is need to employ PGP bacteria strains with capabilities to solubilize inorganic phosphates (PSB) in order to improve the availability of phosphorus for crops that are susceptible to soil phosphorus deficiency such as rice.

Wu et al. (2014), Beneduzi et al. (2013) and Mamta et al. (2010) have successfully isolated PGPR bacteria, such as Bacillus sp. and Pseudomonas sp. from different sources, which also showed PSB capabilities. These bacteria have shown different capabilities in improving growth and yield of Stevia rebaudiana, sugarcane and cotton. Considering the differences in PGP and PSB capabilities of different bacteria strains from different sources, a previous study by Musa and Ikhajiagbe (2020) isolated culturable bacteria from ferruginous soils comparative to control soil in order to investigate their PSB capabilities for future use in soil improvement. Six soil samples of different ferruginous levels and a control were assayed in Pikovskaya's medium at $27^{\circ} \mathrm{C}$ with 7.5 $\mathrm{pH}$ for 7days. Six distinct isolates were observed among which three species (isolate BCAC2-Bacillus sp., isolate EMBF2- Klebsiella sp. and isolate BCAF1- Proteus sp.) showed phosphate-solubilizing capabilities and plant growth-promoting (PGP) capacities such as IAA and siderophores production. The isolates were also observed to show tolerance to acidic and alkaline media. Therefore, the current study was conducted to investigate the possibilities of these bacteria isolates (Bacillus sp., Klebsiella sp. and Proteus sp.) obtained from ferruginous soils and a control to influence the growth parameters of rice plant in an in vitro experimental setup. The current study may improve agricultural sustainability and improve crop productivity.

\section{Methods}

\section{Collection of microbial isolates}

Three phosphate-solubilizing bacteria species (isolates $\mathrm{BCAC2}$ EMBF2 and BCAF1, respectively) that were previously isolated from ferruginous ultisol and humus soil in an earlier study in Benin City by Musa and Ikhajiagbe (2020). The three bacterial isolates were isolated by using serial dilution and were subjected to biochemical test 
using catalase, indole, citrate, nitrogen fixing activity and bromotyhmol blue test. The PSB screening was done by drop plate method onto a developed Pikovskaya's growth medium. The isolates were also tested for $\mathrm{pH}$ tolerance level with HCL following (Mondala et al. 2016). PGP capabilities of the isolates were determined by IAA and siderophores production following Gupta et al. (2012b) and Balkar (2013), respectively. The isolates were eventually streak onto petri dishes for molecular identification using $16 \mathrm{~S}$ rRNA sequencing.

\section{Molecular characterization of phosphate solubilizing bacteria using $16 \mathrm{~S}$ rRNA}

DNA was extracted using the protocol stated by Saitou and Nei (1987). Briefly, single colonies grown on medium were transferred to $1.5 \mathrm{ml}$ of liquid medium and cultures were left to grow on a shaker for $48 \mathrm{~h}$ at $28{ }^{\circ} \mathrm{C}$. After this period, cultures were centrifuged at $4600 \mathrm{~g}$ for $5 \mathrm{~min}$. The resulting pellets were resuspended in $520 \mu \mathrm{l}$ of TE buffer (10 mMTris- $\mathrm{HCl}, 1 \mathrm{mM}$ EDTA, pH 8.0). 15 microliters of $20 \%$ SDS and $3 \mu \mathrm{l}$ of Proteinase $\mathrm{K}(20 \mathrm{mg} / \mathrm{ml})$ were then added. The mixture was incubated for 1 hour at $37{ }^{\circ} \mathrm{C}$, then $100 \mu \mathrm{l}$ of $5 \mathrm{M} \mathrm{NaCl}$ and $80 \mu \mathrm{L}$ of a $10 \% \mathrm{CTAB}$ solution in $0.7 \mathrm{M} \mathrm{NaCl}$ were added and votexed. The suspension was incubated for $10 \mathrm{~min}$ at $65^{\circ} \mathrm{C}$ and kept in ice for $15 \mathrm{~min}$. An equal volume of chloroform: isoamyl alcohol (24:1) was added, followed by incubation in ice for $5 \mathrm{~min}$ and centrifugation at $7200 \mathrm{~g}$ for $20 \mathrm{~min}$. The DNA was collected by centrifugation at $13000 \mathrm{~g}$ for $10 \mathrm{~min}$, washed with $500 \mu \mathrm{l}$ of $70 \%$ ethanol, air-dried at room temperature for approximately three hours and finally dissolved in $50 \mu \mathrm{l}$ of TE buffer. The 16S rRNA gene was amplified by using polymerase chain reaction (PCR-MJ Research PTC-100) using primers 27F 5' - AGA GTT TGA TCM TGG CTC AG-3' and - 1525R, 5'-AAGGAGGTGATCCAGCC-3' by using BLAST programme of GeneBank database on NCBI.

\section{Sequencing}

The amplified fragments were sequenced using a Genetic Analyzer 3130xl sequencer from Applied Biosystems using manufacturers' manual, while the sequencing kit used was BigDye terminator v3.1 cycle sequencing kit. Bio-Edit software and Clustal W using MEGA 6 were used for all genetic analysis. The evolutionary history was inferred using the Neighbor-Joining method (Saitou and Nei 1987). The optimal tree with the sum of branch length $=16.34337029$ is shown. The tree is drawn to scale, with branch lengths in the same units as those of the evolutionary distances used to infer the phylogenetic tree. The evolutionary distances were computed using the Maximum Composite Likelihood method (Tamura et al. 2004) in the number units of base substitutions per site. Evolutionary analyses were conducted in MEGA X (Kumar et al. 2018).

\section{Preparation of inoculum}

The pure phosphate solubilizing bacteria (PSB) having plant growth-promoting (PGP) traits (BCAC2, EMBF2 and $\mathrm{BCAF} 1$ ) were prepared by streaking onto agar plates and incubated at $28^{\circ} \mathrm{C}$ for 48 hours. Upon growth after 48 hours, the isolates were inoculated in Nutrient broth which was used to grow the isolate, and then incubated for proliferation of cells and then prepared into $0.5 \mathrm{McF}$ arland Standard with Cat. No (TM50) to standardize the approximate number of bacteria in the suspension. This process was used to prepare $500 \mathrm{~mL}$ of each bacterial isolate and therefore having an average microbial suspension of $1.5 \times 10^{8} \mathrm{cfu} / \mathrm{mL}$.

\section{In vitro seed inoculation}

A soil-free culture experiment was conducted using improved high-yielding rice variety (FARO 44) that was previously obtained from Center for Dryland Agriculture, Bayero University, Kano. Rice seeds were tested for viability following (AOSA 2000). Those seeds that settles at the bottom were considered viable. The viable seeds were sown onto 40 pre-sterilized Petri dishes $(9 \mathrm{~cm}$ diameter) at the rate of 20 seeds per petri dish that was lined with Whatman filter paper. McFarland (1944) standard of the $500 \mathrm{~mL}$ bacterial inoculum was made into three treatments with four replicates $(10,7.5$ and $5.0 \mathrm{~mL})$ of each bacteria. The treatments were added up to make $10 \mathrm{~mL}$ by using distilled water. The control was made to be $10 \mathrm{~mL}$ of distilled water in four replicates. The calculated inoculum volumes were introduced into the petri dishes using $5 \mathrm{~mL}$ syringe and covered at a temperature between 25 and $26.6^{\circ} \mathrm{C}$ as described by Etesami et al. (2014). The three bacteria were coded as ( $\mathrm{A}=$ Bacillus sp., $\mathrm{B}=$ Proteus sp. and $\mathrm{C}=$ Klebsiella sp.). The setup was monitored for 28 days using randomized blocked design and wetted with $5 \mathrm{~mL}$ distilled water-containing nutrient solution (NPK) every 3 days. The plant growth and yield parameters were measured and recorded.

\section{Germination parameters}

Germination parameters are very effective in determining the interaction of PGP bacteria and seeds. The germination test was conducted at $25^{\circ} \mathrm{C}$ in a dark room at the Department of Plant Biology and Biotechnology, University of Benin Postgraduate Research laboratory to determine germination parameters. Following (ISTA 2005) as:

$$
\text { Germination percentage }(\%)=\frac{\text { Number of germinated seeds }}{\text { Total number of seeds sowed }} \times 100
$$


The time at which primary leaf (coleoptile) emerged was observed by monitoring the seed germination after every 6 hours. Imbibition rate was measured by weighing the rice seeds at intervals of 6 hours until an equilibrium weight was observed. The weight (g) was plotted against time (h) following Jean-Francois et al. (2018). Water use efficiency of the seed (\%) was calculated following Archana et al. (2017) as: was determined using a non-destructive method employing Apogee chlorophyll concentration meter. The CCI of the old and new leaf were measured as average of the mesocotyl, mid-seedling and top seedling at $14^{\text {th }}, 21^{\text {st }}$ and $28^{\text {th }}$ days after sowing. Chlorophyll a and b contents were investigated according to methods described by Arnon (1949), Maxwell and Johnson (2000). Leaf area was calculated using an android application (Leaf-IT) following

Water applied - Water obtained after average imbibition $\times 100$.

The average imbibition was attained at 30 hours. Germination time was calculated as the time at which the seed stops imbibition, while the speed of germination (\%) was calculated based on the time of first seed emergence (30 hours) and the average time for complete seed emergence (72 hours) following a formula developed by (Krishnaswamy and Seshu 1990) with a slight modification as:

$$
\text { Speed of germination }=\frac{\text { Number of seed germinated at } 30 \mathrm{~h}}{\text { Number of seed germinated at } 72 \mathrm{~h}}
$$

Julian et al. (2017) at 28 days after sowing. Leaf tip chlorosis and necrosis was measured as the percentage of the total number of leaves produced by plants that showed significant level of chlorosis and necrosis. This was predecided following reports from Ikhajiagbe et al. (2017).

\section{Morphological parameters}

Morphological parameters that are related to growth and yield of rice were investigated. Fresh shoot length, fresh root length and length of the first leaf were calculated in $(\mathrm{cm})$ by using a transparent ruler that was mounted on a white calibrated paper from day 4 to 28 days after sowing. To obtain the dry root length $(\mathrm{cm})$, seedlings were

\section{Biomass parameters}

Weight of fresh seedling (g) was measured using analytical weighing balance daily from the $4^{\text {th }}$ day $-28^{\text {th }}$ day after sowing. Weight of dry seedling (g) was recorded after air drying the seedling for 24 hours and measured using analytical weighing balance. Seedling vigor index was determined according to Abdul-Baki and Anderson (1973) as:

$$
\mathrm{SV}=\frac{\text { Germination percentage } \times \text { means of seedling length }(\text { Root }+ \text { Shoot })}{100}
$$

air-dried for 24 hours and the root was measured from day 4 to 28 days after sowing. The length of internodes $(\mathrm{cm})$ was measured successive nodes using a sample of 5 best seedlings from all treatments weekly, while the number of secondary roots were carefully observed and counted daily.

\section{Physiological parameters}

To analyze the inoculum effect on the growth and yield of the rice plant, physiological parameters were investigated. Total soluble sugar was estimated at week 2 and 4 by oven-drying the tallest leaf at $70^{\circ} \mathrm{C}$ for $24 \mathrm{~h}$ as described by Nelson (1944) with a slight modification by Sankar and Selvaraju (2015). Growth enzyme such as alpha amylase of the seedling extract was determined at day 28 after sowing by DNS method of Lowry et al. (1951) at a pH of 7.5. Chlorophyll content index (CCI)

\section{Statistical analysis}

Data obtained were presented in means and standard errors of four replicates. Data were analyzed following two-way analysis of variance using GENSTAT (8th edition). Where significant $p$-values were obtained, differences between means were separated using Student Newman Keuls Test (Alika 2006).

\section{Results \\ Molecular characterization and phylogenetic analysis of phosphate solubilizing bacteria}

The 16S rRNA gene sequencing (of $1500 \mathrm{bp)}$ results showed the isolate BCAC2 was recognized to be Bacillus cereus strain GGBSU-1, the isolate EMBF2 was identified as Klebsiella variicola strain AUH-KAM-9, while the isolate BCAF1 was identified as Proteus mirabilis strain TL14-1. The three isolates showed 96, 66 and 100 


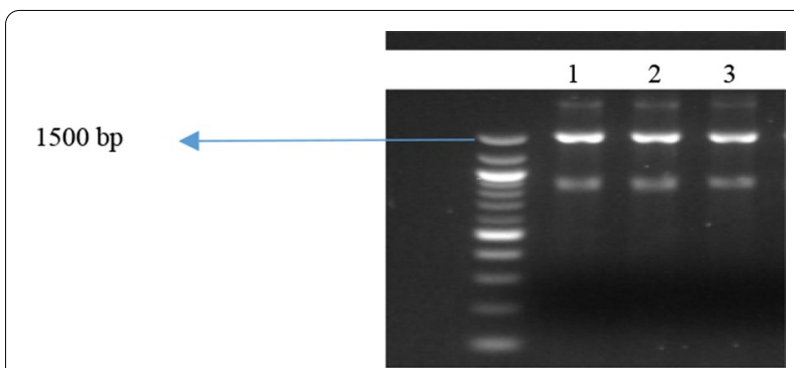

Fig. 1 PCR products of $16 \mathrm{~S} r R N A$ (Line $1=B C A C 2$, Line $2=E M B F 2$, Line 3= BCAF1).

$\%$ resemblance with already sequenced species, respectively, as observed in the neighbor-joining dendrogram (Figs. 15, 16 and 17). The 16S rRNA gene product of all isolates in this study was equal $(1.4 \mathrm{~Kb})$ even though the whole sequencing that includes the entire $1,500 \mathrm{bp}$ region might be useful to distinguish between particular strains. The comparison bands in Fig. 1 and Table 1 showed the three isolates belongs to different taxonomic lineages.

\section{Effect of inoculated PSBs on rice seed germination}

At the first day after sowing, the $10 \mathrm{ml} \mathrm{BiS} \mathrm{(A10)} \mathrm{was}$ observed to show the highest germination percentage (90\%), while the lowest (55\%) germination percentage was observed in the control. There was a significant difference $(p<0.05)$ in the germination percentage at day one between the A10 and the $10 \mathrm{ml}$ PiS (B10). However, there was no significant difference between the A10 and the $10 \mathrm{ml} \mathrm{KiS} \mathrm{(C10).} \mathrm{At} \mathrm{day} \mathrm{2,} \mathrm{the} \mathrm{A10} \mathrm{had} \mathrm{complete}$ germination $(100 \%)$, while there was no increase in germination percentage at the NiS (control). At day 4, all the bacteria inoculated seeds were observed to have full germination. However, the control only had $10 \%$ increase in germination (Table 2).

The time at which seed coleoptile appears (APC) was studied (Fig. 2; Table 2). The results showed that the A10 had the first APC at 24hours, while delay was observed in $\mathrm{PiS}$ and KiS. The control setup had the latest APC of 48 hours. Water use efficiency (WUE) was also investigated after imbibition has been achieved at 30 hours; the control was observed to show the least WUE (38\%), while the A10 showed the highest WUE (61\%). A significant difference $(P<0.05)$ was also observed between all the bacteriainoculated seeds and the control. Seed germination time (GTM) which was calculated as the time at which the seeds stop imbibition were also monitored. The $10 \mathrm{ml} \mathrm{BiS}$ (A10), $7.5 \mathrm{ml} \mathrm{BiS} \mathrm{(A7.5),} 5.0 \mathrm{ml} \mathrm{BiS} \mathrm{(A5),} 10 \mathrm{ml} \mathrm{PiS} \mathrm{(B10),}$ $10 \mathrm{ml} \mathrm{KiS} \mathrm{(C10),} 7.5 \mathrm{ml} \mathrm{KiS} \mathrm{(C7.5)} \mathrm{and} \mathrm{5.0} \mathrm{ML} \mathrm{KiS} \mathrm{(C5)}$ stopped imbibition at the $30^{\text {th }}$ hour after sowing, while the $7.5 \mathrm{ml} \mathrm{PiS} \mathrm{(B7.5)} \mathrm{and} 5.0 \mathrm{ml} \mathrm{PiS} \mathrm{(B5),} \mathrm{stopped} \mathrm{imbi-}$ bition at $36^{\text {th }}$ hour. The control (D10) was observed to stop imbibition at $42^{\text {nd }}$ hour which showed delayed imbibition. The A10 was observed to show highest speed of germination (9\%), while the lowest speed of germination was observed in the B7.5 and the control. Generally, the germination results indicated the highest positive influence of the BiS compared to PiS and KiS, while the control showed the lowest influence (1\%).

The present study investigated the rice seed imbibition rate. Five best seeds from A10, B10, C10 and the control setups were investigated for imbibition rate and presented in a graph of weight against imbibition time (Fig. 3). The A10 was observed to have the highest $(0.034 \mathrm{~g})$ seed weight from 6 to 42 hours of the imbibition study, while the control was observed to show the lowest seed weight $(0.029 \mathrm{~g})$. At 30 hours, imbibition was observed in the BiS, PiS and KiS, while the imbibition was delayed in the control until 36 hours after sowing. The result showed that the BiS had less time to germinate compared to $\mathrm{PiS}$ and $\mathrm{KiS}$. However, the control took longer time to germinate.

\section{Effect of inoculated PSBs on rice seedling morphological parameters}

Significant differences (Table 3) were observed in rice shoot length between the different bacterial inoculations at varying days after sowing (DAS). The A10 showed the highest (80\%) shoot length at all the reported DAS, while the control was observed to show the least shoot length (31\%) at all the reported DAS. An increase in the inoculum concentration was also observed to improve the rice shoot length throughout the study. However, the C7.5 and B7.5 showed no significant difference throughout the study.

The effect of the three inoculations (Bacillus sp., Proteus sp. and Klebsiella sp.) on rice seedling morphology was further investigated by studying the fresh and dry root length (Table 4). The A10 was observed to show the longest root length (64\%) from 4 to $28^{\text {th }}$ DAS compared to the control (25\%). Furthermore, the root length in KiS was observed to be significantly higher than the root length in the PiS. Meanwhile, between day $21^{\text {st }}$ to $28^{\text {th }} \mathrm{DAS}$, there was no significant different in root length between PiS, KiS and the control. The dry root length was also observed to show similar trend (Table 5).

The yield of rice seedling was determined by the distance between successive nodes. The length of internode (cm) was presented in Table 6. At 7DAS, all seedlings showed no presence of internode, while at 14DAS, the growing rice seedling in the A10 showed the highest internode length $(3.1 \mathrm{~cm})$ compared to the control which showed no internode. At 28 DAS, a significant increase in the internode length was observed in the growing 
Table 1. Gene sequence of isolates

$\mathrm{S} / \mathrm{N}$ Isolates Identity Gene sequence

1 BCAC2 Bacillus cereus $G G C$
strain GGBSU-1

GGGGCATGCCTAACACATGCAAGTCGAACGGTAACAGGAAGCAGCTTGCTGCTTCGCTGACGAGTGGCGGACGGGTGAGTA ATGTCTGGGAAACTGCCTGATGGAGGGGGATAACTACTGGAAACGGTAGCTAATACCGCATAATGTCGCAGGACCAAAGAG GGGGACCTTCGGGCCTCTTGCCATCAGATGTGCCCAGATGGGATTAGCTTGTTGGTGAGGTAACGGCTCACCAAGGCG ACGATCCCTAGCTGGTCTGAGAGGATGACCAGCCACACTGGAACTGAGACACGGTCCAGACTCCTACGGGAGGCAGCA GTGGGGAATATTGCACAATGGGCGCAAGCCTGATGCAGCCATGCCGCGTGTATGAAGAAGGCCTTCGGGTTGTAAAGTACT TTCAGCGGGGAGGAAGGGGATAAGGCTAATAACCTTGTTCATTGACGTTACCCGCAGAAGAAGCACCGGCTAACTCCG TGCCAGCAGCCGCGGTAATACGGAGGGTGCAAGCGTTAATCGGAATTACTGGGCGTAAAGCGCACGCAGGCGGTCTGT CAAGTCGGATGTGAAATCCCCGGGCTCAACCTGGGAACTGCATTCGAAACTGGCAGGCTGGAGTCTTGTAGAGGGGGG TAGAATTCCAGGTGTAGCGGTGAAATGCGTAGAGATCTGGAGGAATACCGGTGGGCGAAGGCGGCCCCCTGGACAAAG ACTGACGCTCAGGTGCGAAAGCGTGGGGAGCAAACAGGATTAGATACCCTGGTAGTCCACGCCGTAAACGATGTCTACTTG GAGGTTGTGCCCTTGAGGCGTGGCTTCCGGAGCTAACGCGTTAAGTAGACCGCCTGGGGAGTACGGCCGCAAGGTTAA AACTCAAATGAATTGACGGGGGCCCGCACAAGCGGTGGAGCATGTGGTTTAATTCGATGCAACGCGAAGAACCTTACC TGGTTTTGACATCCACAGAAGTTTNCAGAGATGNGAATGTGCCTTTGGGAACTGTGAGACAGGTGCTGCATGGCTGTCG TCAGCTCGTGTTGTGAAATGTTGGGTTAAGTCCCGCAACGAGCGCAACCCTTATCCTTTGTTGCCAGCGGTCCGGCCGGGA ACTCAAAGGAGACTGCCAGTGATAAACTGGAGGAAGGTGGGGATGACGTCAAGTCATCATGGCCCTTACGACCAGGGC TACACACGTGCTACAATGGCGCATACAAAGAGAAGCGACCTCGCGAGAGCAAGCGGACCTCATAAAGTGCGTCGTAGT CCGGACTGGAGTCTGCAACTCGACTCCATGAAGTCGGAATCGCTAGTAATCGTGGATCAGAATGCCACGGTGAATACGTTC CCGGGCCTTGTACACACCGCCCGTCACACCATGGGAGTGGGTTGCAAAAGAAGTAGGTAGCTTAACCTTCGGGAGGGG GCTTCCCCAT

2 EMBF2 Klebsiella variicola

GGGGCATGCCTAACACATGCAAGTCGAACGGTAACAGGAAGCAGCTTGCTGCTTCGCTGACGAGTGGCGGACGGGTGAGTA strain AUH- $\quad$ ATGTCTGGGAAACTGCCTGATGGAGGGGGATAACTACTGGAAACGGTAGCTAATACCGCATAATGTCGCAGGACCAAAGAG KAM-9 GGGGACCTTCGGGCCTCTTGCCATCAGATGTGCCCAGATGGGATTAGCTTGTTGGTGAGGTAACGGCTCACCAAGGCG ACGATCCCTAGCTGGTCTGAGAGGATGACCAGCCACACTGGAACTGAGACACGGTCCAGACTCCTACGGGAGGCAGCA GTGGGGAATATTGCACAATGGGCGCAAGCCTGATGCAGCCATGCCGCGTGTATGAAGAAGGCCTTCGGGTTGTAAAGTACT TTCAGCGGGGAGGAAGGGGATAAGGCTAATAACCTTGTTCATTGACGTTACCCGCAGAAGAAGCACCGGCTAACTCCG TGCCAGCAGCCGCGGTAATACGGAGGGTGCAAGCGTTAATCGGAATTACTGGGCGTAAAGCGCACGCAGGCGGTCTGT CAAGTCGGATGTGAAATCCCCGGGCTCAACCTGGGAACTGCATTCGAAACTGGCAGGCTGGAGTCTTGTAGAGGGGGG TAGAATTCCAGGTGTAGCGGTGAAATGCGTAGAGATCTGGAGGAATACCGGTGGGCGAAGGCGGCCCCCTGGACAAAG ACTGACGCTCAGGTGCGAAAGCGTGGGGAGCAAACAGGATTAGATACCCTGGTAGTCCACGCCGTAAACGATGTCTACTTG GAGGTTGTGCCCTTGAGGCGTGGCTTCCGGAGCTAACGCGTTAAGTAGACCGCCTGGGGAGTACGGCCGCAAGGTTAA AACTCAAATGAATTGACGGGGGCCCGCACAAGCGGTGGAGCATGTGGTTTAATTCGATGCAACGCGAAGAACCTTACC TGGTTTTGACATCCACAGAAGTTTNCAGAGATGNGAATGTGCCTTTGGGAACTGTGAGACAGGTGCTGCATGGCTGTCG TCAGCTCGTGTTGTGAAATGTTGGGTTAAGTCCCGCAACGAGCGCAACCCTTATCCTTTGTTGCCAGCGGTCCGGCCGGGA ACTCAAAGGAGACTGCCAGTGATAAACTGGAGGAAGGTGGGGATGACGTCAAGTCATCATGGCCCTTACGACCAGGGC TACACACGTGCTACAATGGCGCATACAAAGAGAAGCGACCTCGCGAGAGCAAGCGGACCTCATAAAGTGCGTCGTAGT CCGGACTGGAGTCTGCAACTCGACTCCATGAAGTCGGAATCGCTAGTAATCGTGGATCAGAATGCCACGGTGAATACGTTC CCGGGCCTTGTACACACCGCCCGTCACACCATGGGAGTGGGTTGCAAAAGAAGTAGGTAGCTTAACCTTCGGGAGGGG GCTTCCCCAT

3 BCAF1 Proteus mirabilis

GGGGCGCATCTACACATGCAGTCGAGCGGTAACAGGAGAAAGCTTGCTTTCTTGCTGACGAGCGGCGGACGGGTGAGTAAT strain TL14-1 GTATGGGGATCTGCCCGATAGAGGGGGATAACTACTGGAAACGGTGGCTAATACCGCATAATGTCTACGGACCAAAGCAGG GGCTCTTCGGACCTTGCACTATCGGATGAACCCATATGGGATTAGCTAGTAGGTGGGGTAAAGGCTCACCTAGGCGACGAT CTCTAGCTGGTCTGAGAGGATGATCAGCCACACTGGGACTGAGACACGGCCCAGACTCCTACGGGAGGCAGCAGTGGG GAATATTGCACAATGGGCGCAAGCCTGATGCAGCCATGCCGCGTGTATGAAGAAGGCCTTAGGGTTGTAAAGTACTTTCAG CGGGGAGGAAGGTGATAAGGTTAATACCCTTATCAATTGACGTTACCCGCAGAAGAAGCACCGGCTAACTCCGTGCCAGCA GCCGCGGTAATACGGAGGGTGCAAGCGTTAATCGGAATTACTGGGCGTAAAGCGCACGCAGGCGGTCAATTAAGTCAG ATGTGAAAGCCCCGAGCTTAACTTGGGAATTGCATCTGAAACTGGTTGGCTAGAGTCTTGTAGAGGGGGGGTAGAATTCCA TGTGTAGCGGTGAAATGCGTAGAGATGTGGAGGAATACCGGTGGCGAAGGCGGCCCCCTGGACAAAGACTGACGCTCA GGTGCGAAAGCGTGGGGAGCAAACAGGATTAGATACCCTGGTAGTCCACGCTGTAAACGATGTCGATTTAGAGGTTGTGGT CTTGAACCGTGGCTTCTGGAGTAACGCGTTAAATCGACCGCCTGGGGAGTACGGCCGCAAGGTTAAAACTCAAATGAATTG ACGGGGGCCCGCACAAGCGGTGGAGCATGTGGTTTAATTCGATGCAACGCGAAGAACCTTACCTACTCTTGACATCCAGCA ATCCTTTAGAGATAGAGGAGTGCCTTCGGGAACGCTGAGACAGGTGCTGCATGGCTGTCGTCAGCTCGTGTTGTGAAATGT TGGGTTAAGTCCCGCAACGAGCGCAACCCTTATCCTTTGTTGCCAGCACGTGATGGTGGGAACTCAAAGGAGACTGCCGGT GATAAACCGGAGGAAGGTGGGGATGACGTCAAGTCATCATGGCCCTTACGAGTAGGGCTACACACGTGCTACAATGGCAGA TACAAAGAGAAGCGACCTCGCGAGAGCAAGCGGAACTCATAAAGTCTGTCGTAGTCCGGATTGGAGTCTGCAACTCGA CTCCATGAAGTCGGAATCGCTAGTAATCGTAGATCAGAATGCTACGGTGAATACGTTCCCGGGCCTTGTACACACCGCCCG TCACACCATGGGAGTGGGTTGCAAAAGAAGTAGGTAGCTTAACCTTCGGGAGGGCGCTACCACTTGGATTCAA

seedling from $5.1 \mathrm{~cm}$ in $\mathrm{BiS}$ compared to the control $(1.1$ $\mathrm{cm})$.

To verify the effect of the PSB bacteria with PGP capabilities on rice seedlings, the number of secondary roots in all the experimental setup was determined (Table 7). The results showed a significant increase $(P<0.05)$ in the number of secondary root in the setup inoculated with the bacteria compared to the control for all the analyzed days. At 4DAS, no secondary root was observed in the B10, B7.5, C5 and the control, while at 6DAS, (3) secondary roots were seen in the control. 
Table 2 Germination parameters of rice inoculated with PSBs and control

\begin{tabular}{|c|c|c|c|c|c|c|c|c|}
\hline \multirow[t]{2}{*}{ Samples } & \multicolumn{4}{|c|}{ Germination (\%) on } & \multirow[t]{2}{*}{ APC (Hrs) } & \multirow[t]{2}{*}{ WUE (\%) } & \multirow[t]{2}{*}{ GTM (Hrs) } & \multirow[t]{2}{*}{ SGM (\%) } \\
\hline & 1st DAS & 2nd DAS & 3rd DAS & 4th DAS & & & & \\
\hline A 10 & $90 \pm 5.7^{\mathrm{a}}$ & $100 \pm 2.3^{\mathrm{a}}$ & $100 \pm 2.1^{\mathrm{a}}$ & $100 \pm 2.1^{\mathrm{a}}$ & $24 \pm 0.5^{a}$ & $61 \pm 2.1^{\mathrm{a}}$ & $30 \pm 0.2^{\mathrm{a}}$ & $9 \pm 0.5^{\mathrm{a}}$ \\
\hline A 7.5 & $85 \pm 2.8^{\mathrm{a}}$ & $90 \pm 2.8^{\mathrm{a}}$ & $95 \pm 2.4^{\mathrm{a}}$ & $100 \pm 2.4^{\mathrm{a}}$ & $30 \pm 0.5^{b}$ & $60 \pm 5.7^{a}$ & $30 \pm 0.2^{\mathrm{a}}$ & $8.5 \pm 0.6^{\mathrm{a}}$ \\
\hline A 5.0 & $60 \pm 2.3^{b}$ & $70 \pm 2.5^{\mathrm{ba}}$ & $90 \pm 2.6^{a}$ & $100 \pm 5.3^{\mathrm{a}}$ & $30 \pm 0.5 \mathrm{cb}$ & $56 \pm 0.4^{c}$ & $30 \pm 0.5^{a}$ & $2 \pm 0.5^{b}$ \\
\hline B 10 & $70 \pm 2.1^{\mathrm{ab}}$ & $75 \pm 5.3^{c}$ & $80 \pm 5.1^{\mathrm{a}}$ & $90 \pm 5.7^{a}$ & $42 \pm 0.5^{d}$ & $51 \pm 2.1^{d}$ & $30 \pm 5.3^{a}$ & $7 \pm 0.5^{\mathrm{a}}$ \\
\hline B 7.5 & $85 \pm 5.7^{\mathrm{a}}$ & $85 \pm 5.4^{\mathrm{ba}}$ & $85 \pm 5.6^{\mathrm{a}}$ & $100 \pm 5.7^{\mathrm{a}}$ & $30 \pm 0.5 \mathrm{eb}$ & $49 \pm 2.1^{d}$ & $36 \pm 0.4^{b}$ & $1 \pm 0.0^{c}$ \\
\hline B 5.0 & $50 \pm 2.3^{\mathrm{cb}}$ & $50 \pm 2.4^{d}$ & $60 \pm 2.4^{b}$ & $65 \pm 5.7^{b}$ & $48 \pm 0.5^{f}$ & $43 \pm 3.0^{f}$ & $36 \pm 0.2^{b}$ & $2.5 \pm 0.2^{d}$ \\
\hline C 10 & $85 \pm 2.1^{\mathrm{a}}$ & $85 \pm 2.1^{\mathrm{a}}$ & $100 \pm 5.7^{\mathrm{a}}$ & $100 \pm 2.8^{\mathrm{a}}$ & $30 \pm 0.5^{\mathrm{gb}}$ & $53 \pm 0.4^{d}$ & $30 \pm 0.4^{\mathrm{a}}$ & $5.6 \pm 0.05^{e}$ \\
\hline C 7.5 & $85 \pm 3.3^{\mathrm{a}}$ & $90 \pm 0.9^{a}$ & $95 \pm 2.8^{\mathrm{a}}$ & $100 \pm 5.7^{\mathrm{a}}$ & $36 \pm 0.5^{h}$ & $51 \pm 0.2^{d}$ & $30 \pm 0.4^{\mathrm{a}}$ & $8.5 \pm 0.2^{\mathrm{a}}$ \\
\hline C 5.0 & $60 \pm 2.4^{\mathrm{db}}$ & $60 \pm 2.5^{\mathrm{e}}$ & $70 \pm 2.8^{c}$ & $75 \pm 2.4^{c}$ & $30 \pm 0.5^{\mathrm{ib}}$ & $51 \pm 0.3^{d}$ & $30 \pm 0.4^{\mathrm{a}}$ & $6 \pm 0.5^{f}$ \\
\hline D 10 & $55 \pm 3.4^{\mathrm{eb}}$ & $55 \pm 2.5^{f}$ & $55 \pm 5.7^{d}$ & $65 \pm 2.8^{d}$ & $48 \pm 0.5^{j}$ & $38 \pm 3.1^{j}$ & $42 \pm 0.1^{a}$ & $1 \pm 0.0^{c}$ \\
\hline
\end{tabular}

Results with similar alphabetic superscripts on same column did not differ from each other ( $p>0.05$ ). Results were in mean and standard error of four replicates. $\mathrm{DAS}=$ Day after sowing, $\mathrm{APC}=$ Appearance of coleoptile, $\mathrm{WUC}=$ Water used efficiency, $\mathrm{GTM}=$ Germination time, $\mathrm{SGM}=\mathrm{Speed}$ of germination. $\mathrm{A} 10$, A7.5 and $\mathrm{A} 5.0=$ $10 \mathrm{ml}, 7.5 \mathrm{ml}$ and $5.0 \mathrm{ml}$ of Bacillus sp., respectively. B10, B7.5 and B5.0 = $10 \mathrm{ml}, 7.5 \mathrm{ml}$ and $5.0 \mathrm{ml}$ Proteus sp. respectively. C10, C7.5 and C5.0 = $10 \mathrm{ml}, 7.5 \mathrm{ml}$ and $5.0 \mathrm{ml}$ of Klebsiella sp., respectively. D10 $=10 \mathrm{ml}$ of control.

The length of first leaf in the growing rice seedling in the current experimental setup was also observed (Fig. 4). The A10 was observed to show the highest length $(\mathrm{cm})$ of the first leaf at 1, 2, 3 and 4 weeks after sowing (WAS), while the control soil was observed to show the least length. A delay in first leaf emergence was also observed in the B7.5, C5 and the control until 2WAS. A significant difference was obtained between the A10 and all other bacteria inoculated setups (PiS and KiS). The significant increase in the length of the first leaf as observed in the A10 is indicating the effectiveness of the Bacillus cereus strain GGBSU-1 in improving yield and growth of rice.

\section{Effect of inoculated PSBs on rice seedling physiological parameters}

The effect of the bacterial inocula on the total sugar contents of rice seedling was significant at 2 and 4WAS in all the test samples (Fig. 5). At 2WAS, the content of total sugars was the highest in the $\mathrm{A} 10\left(18.0 \mathrm{mg} / \mathrm{g}^{-1} \mathrm{fw}\right)$ and the lowest $\left(2.6 \mathrm{mg} / \mathrm{g}^{-1} \mathrm{fw}\right)$ in the control. A similar trend was also observed at 4WAS. Furthermore, it was observed that the total soluble sugar of $\mathrm{C} 10$ at 2 and 4WAS was significantly higher than B10. However, there was no significant differences between C7.5 and B7.5.

Table 8 shows Chlorophyll-a ( $\mathrm{Chl}$ a) and b (Chl b) contents of rice seedlings at 2 and 4WAS. For $\mathrm{Chl}$ a, the highest value was observed in the A10 $\left(6.4 \mathrm{mg} / \mathrm{cm}^{2} \mathrm{fw}\right)$, while the least was observed in the control $\left(2.3 \mathrm{mg} / \mathrm{cm}^{2}\right.$ $\mathrm{fw})$ at 2 WAS. Similar trend was also observed at 4WAS. However, there was no significant difference $(P>0.05)$ in $\mathrm{Chl}$ a between A10, A7.5 and C10. Furthermore, a significant difference $(P<0.05)$ was observed in the old and new leaf chlorophyll content index (CCI) between the
$\mathrm{BiS}$ and the control. However, no significant difference was observed in $\mathrm{CCI}$ within the $\mathrm{BiS}, \mathrm{PiS}$ and $\mathrm{KiS}$.

During the study, necrosis and chlorosis were observed at the leaf tip of rice seedlings (Fig. 6) at 2, 3 and 4WAS and recorded in Table 8. At 2WAS, all seedlings in the control, C5, B5, B7.5 and A5 showed observable signs of different levels of chlorosis and necrosis, while the highest percentage chlorosis and necrosis $(66.6-76 \%)$ were found in the control at 3 and 4WAS. Delayed chlorosis and necrosis were observed in the A7.5, B10 and C10 treatments until 3WAS. No chlorosis were detected in A10 and C7.5 setup throughout the study.

The leaf area is one of the determinants of growth an yield of plants, in the current study, the highest leaf area $\left(2.0 \mathrm{~cm}^{2}\right)$ was observed in the rice $\mathrm{BiS}$, while the lowest $\left(0.15 \mathrm{~cm}^{2}\right)$ was observed in the control using leaf-IT mobile application (Fig. 7). Significant difference was observed between the A10 and all other bacteria inocula (PiS and KiS).

Figure 8 indicates that $\mathrm{BiS}, \mathrm{PiS}$ and $\mathrm{KiS}$ showed a significant improvement in seedling $\alpha$-amylase at 2 and 4WAS. At 2WAS, the C10 was observed to show the highest $\alpha$-amylase $(15.8 \mathrm{U})$, while the control was observed to show the least (6.7 U). At 4WAS, a change in trend was observed where the A10 was observed to show the highest $\alpha$-amylase (45.3 U). However, the control was still observed to show the least $\alpha$-amylase $(18.4 \mathrm{U})$ at 4 WAS. Significant differences were also observed between the other inocula (PiS and KiS) and the control. 


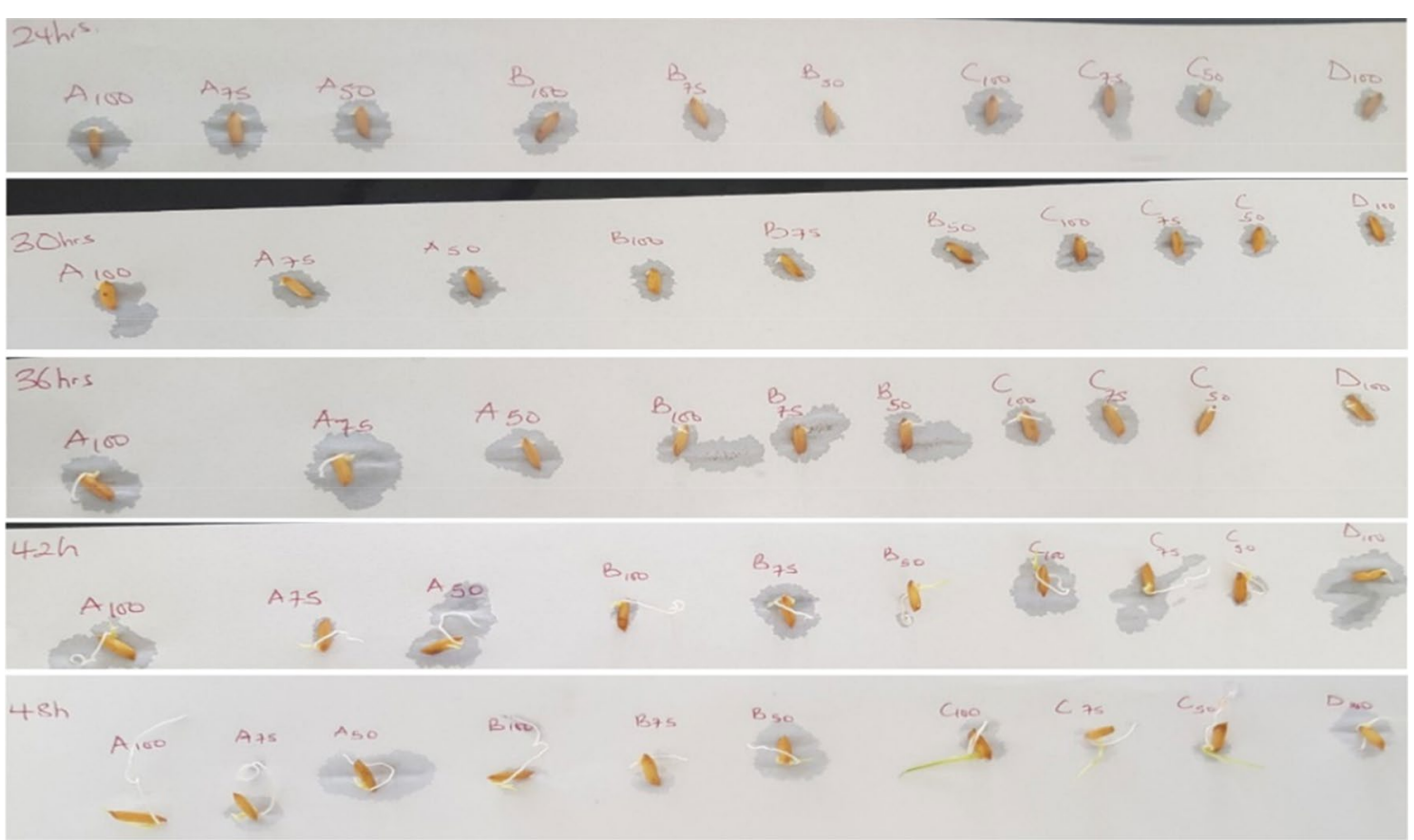

Fig. 2 Appearance of rice seed coleoptile after exposure to experimental treatments.
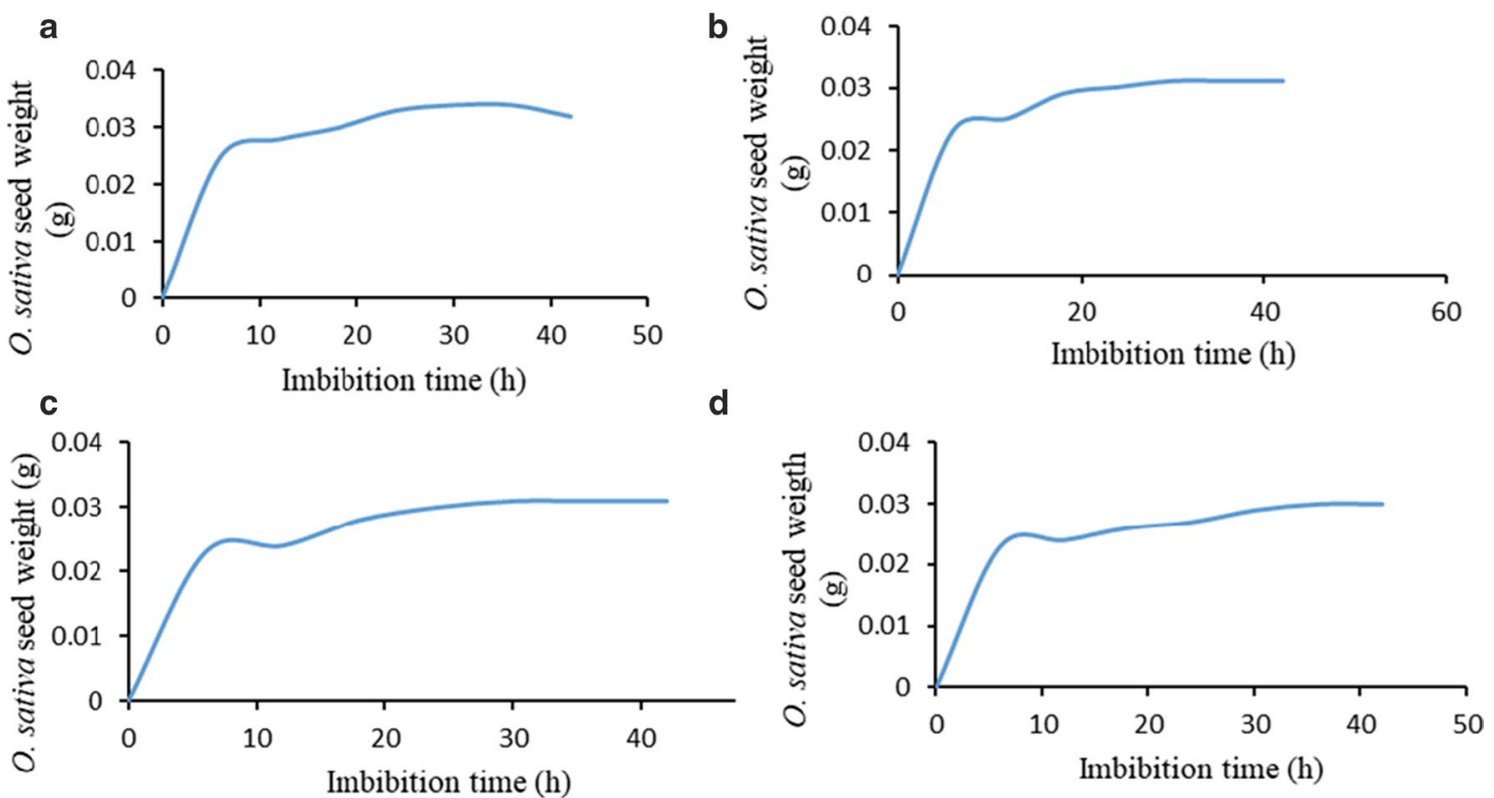

Fig. 3 Imbibition rate of rice germinants after exposure to treatments

\section{Effect of inoculated PSBs on rice seedling biomass parameters}

Table 9 shows a significant increase in the dry and fresh shoot weight in the A10 compared to the control. However, there was no significant differences between the
PiS and KiS, even though the KiS was slightly higher than the PiS at all the assayed days. 
Table 3 Effect of PSB inoculum on in vitro rice fresh shoot length

\begin{tabular}{|c|c|c|c|c|c|c|}
\hline \multirow[t]{2}{*}{ Inoculum } & \multicolumn{6}{|c|}{ Fresh shoot length $(\mathrm{cm})$ on } \\
\hline & 4DAS & 5DAS & 6DAS & 2WAS & 3WAS & 4WAS \\
\hline$A / 10$ & $2.6 \pm 0.07^{a}$ & $4.4 \pm 0.22^{\mathrm{a}}$ & $5.3 \pm 0.36^{\mathrm{a}}$ & $8.5 \pm 0.02^{a}$ & $11.9 \pm 0.64^{\mathrm{a}}$ & $15.4 \pm 0.35^{a}$ \\
\hline$A / 7.5$ & $1.9 \pm 0.07^{b}$ & $3.8 \pm 0.14^{\mathrm{a}}$ & $5.3 \pm 0.21^{\mathrm{a}}$ & $7.5 \pm 0.38^{b}$ & $10.5 \pm 0.26^{b}$ & $13.2 \pm 0.36^{b}$ \\
\hline $\mathrm{A} / 5$ & $1.4 \pm 0.06^{c}$ & $3.7 \pm 0.25^{\mathrm{a}}$ & $4.5 \pm 0.08^{b}$ & $7.1 \pm 0.35^{b}$ & $9.5 \pm 0.00^{c}$ & $11.2 \pm 0.23^{c}$ \\
\hline$B / 10$ & $1.3 \pm 0.07^{c}$ & $2.8 \pm 0.28^{b}$ & $3.2 \pm 0.11^{c}$ & $5.7 \pm 0.04^{c}$ & $6.8 \pm 0.25^{d}$ & $8.4 \pm 0.13^{d}$ \\
\hline $\mathrm{B} / 7.5$ & $1.2 \pm 0.03^{c}$ & $3.2 \pm 0.10^{c}$ & $3.3 \pm 0.06^{c}$ & $5.0 \pm 0.09^{c}$ & $6.2 \pm 0.37^{d}$ & $7.0 \pm 0.43^{\mathrm{e}}$ \\
\hline$B / 5$ & $1.4 \pm 0.16^{c}$ & $3.2 \pm 0.02^{\mathrm{ac}}$ & $3.3 \pm 0.63^{c}$ & $4.5 \pm 0.07^{d}$ & $5.3 \pm 0.11^{e}$ & $6.0 \pm 0.18^{f}$ \\
\hline$C / 10$ & $1.9 \pm 0.18^{b}$ & $3.4 \pm 0.21^{\mathrm{ac}}$ & $3.4 \pm 0.08^{c}$ & $6.0 \pm 0.26^{e}$ & $7.2 \pm 0.15^{f}$ & $8.9 \pm 0.59^{d}$ \\
\hline $\mathrm{C} / 7.5$ & $1.6 \pm 0.05^{c}$ & $3.7 \pm 0.26^{\mathrm{a}}$ & $3.2 \pm 0.31^{c}$ & $5.0 \pm 0.56^{c}$ & $6.8 \pm 0.34^{d}$ & $7.6 \pm 0.08^{e}$ \\
\hline $\mathrm{C} / 5$ & $1.1 \pm 0.03^{c}$ & $3.2 \pm 0.08^{\mathrm{ac}}$ & $3.4 \pm 0.21^{c}$ & $4.7 \pm 0.10^{d}$ & $6.2 \pm 0.16^{d}$ & $7.9 \pm 0.25^{\mathrm{ed}}$ \\
\hline$D / 10$ & $1.1 \pm 0.03^{j}$ & $2.2 \pm 0.06^{\mathrm{cd}}$ & $2.3 \pm 0.20^{d}$ & $3.7 \pm 30.03^{f}$ & $4.7 \pm 0.20^{g}$ & $4.9 \pm 0.37^{9}$ \\
\hline
\end{tabular}

$\mathrm{DAS}=$ Days after sowing, WAS = Weeks after sowing. Results with similar alphabetic superscripts on same column did not differ from each other ( $\mathrm{p}>0.05$ ). A10, A7.5 and $\mathrm{A} 5.0=10 \mathrm{ml}, 7.5 \mathrm{ml}$ and $5.0 \mathrm{ml}$ of Bacillus sp., respectively. B10, B7.5 and B5.0 = $10 \mathrm{ml}, 7.5 \mathrm{ml}$ and $5.0 \mathrm{ml}$ Proteus sp., respectively. C10, C7.5 and C5.0 = $10 \mathrm{ml}, 7.5$ $\mathrm{ml}$ and $5.0 \mathrm{ml}$ of Klebsiella sp., respectively. D10 $=10 \mathrm{ml}$ of control

Table 4 Effect of PSB inoculum on in vitro rice fresh root

\begin{tabular}{|c|c|c|c|c|c|c|}
\hline \multirow[t]{2}{*}{ Inoculum } & \multicolumn{6}{|c|}{ Fresh root length $(\mathrm{cm})$ on } \\
\hline & 4DAS & 5DAS & 6DAS & 2WAS & 3WAS & 4WAS \\
\hline $\mathrm{A} / 10$ & $3.3 \pm 0.36^{\mathrm{a}}$ & $5.0 \pm 0.08^{\mathrm{a}}$ & $5.2 \pm 0.10^{\mathrm{a}}$ & $7.0 \pm 0.10^{\mathrm{a}}$ & $8.8 \pm 0.24^{\mathrm{a}}$ & $9.3 \pm 0.01^{\mathrm{a}}$ \\
\hline $\mathrm{A} / 7.5$ & $2.8 \pm 0.21^{b}$ & $4.2 \pm 0.15^{b}$ & $4.6 \pm 0.30^{b}$ & $5.2 \pm 0.06^{b}$ & $6.8 \pm 0.38^{b}$ & $7.1 \pm 0.04^{b}$ \\
\hline $\mathrm{A} / 5$ & $2.2 \pm 0.88^{c}$ & $4.3 \pm 0.49^{b}$ & $4.6 \pm 0.26^{b}$ & $5.1 \pm 0.30^{b}$ & $6.8 \pm 0.37^{b}$ & $7.0 \pm 0.23^{b}$ \\
\hline$B / 10$ & $1.2 \pm 0.11^{d}$ & $3.3 \pm 0.05^{c}$ & $3.3 \pm 0.06^{c}$ & $3.7 \pm 0.13^{c}$ & $4.9 \pm 0.44^{c}$ & $5.6 \pm 0.11^{c}$ \\
\hline $\mathrm{B} / 7.5$ & $1.1 \pm 0.06^{\mathrm{d}}$ & $2.6 \pm 0.24^{d}$ & $3.1 \pm 0.07^{c}$ & $3.2 \pm 0.16^{d}$ & $4.4 \pm 0.15^{c}$ & $5.1 \pm 0.23^{c}$ \\
\hline$B / 5$ & $1.7 \pm 0.63^{e}$ & $3.2 \pm 0.06^{c}$ & $3.3 \pm 0.07^{c}$ & $3.6 \pm 0.03^{c}$ & $4.1 \pm 0.07^{d}$ & $5.1 \pm 0.03^{c}$ \\
\hline$C / 10$ & $3.2 \pm 0.08^{e}$ & $4.5 \pm 0.09^{b}$ & $4.7 \pm 0.12^{b}$ & $4.9 \pm 0.11^{\mathrm{e}}$ & $5.3 \pm 0.33^{e}$ & $5.9 \pm 0.06^{c}$ \\
\hline $\mathrm{C} / 7.5$ & $2.6 \pm 0.31^{b}$ & $3.3 \pm 0.12^{c}$ & $3.5 \pm 0.14^{c}$ & $4.4 \pm 0.34^{f}$ & $5.3 \pm 0.32^{e}$ & $5.6 \pm 0.05^{c}$ \\
\hline $\mathrm{C} / 5$ & $1.7 \pm 0.21^{\mathrm{e}}$ & $3.5 \pm 0.28^{c}$ & $3.7 \pm 0.38^{c}$ & $4.6 \pm 0.15^{e}$ & $5.4 \pm 0.30^{e}$ & $5.5 \pm 0.07^{c}$ \\
\hline $\mathrm{D} / 10$ & $0.6 \pm 0.20^{f}$ & $1.7 \pm 0.27^{\mathrm{e}}$ & $2.0 \pm 0.25^{d}$ & $3.1 \pm 0.03^{d}$ & $3.8 \pm 0.23^{f}$ & $4.0 \pm 0.09^{d}$ \\
\hline
\end{tabular}

$\mathrm{DAS}=$ Days after sowing, WAS $=$ Weeks after sowing. Results with similar alphabetic superscripts on same column did not differ from each other $(p>0.05)$. A10, A7.5 and $\mathrm{A} 5.0=10 \mathrm{ml}, 7.5 \mathrm{ml}$ and $5.0 \mathrm{ml}$ of Bacillus sp., respectively. B10, B7.5 and B5.0 = $10 \mathrm{ml}, 7.5 \mathrm{ml}$ and $5.0 \mathrm{ml}$ Proteus sp., respectively. C10, C7.5 and C5.0 = $10 \mathrm{ml}, 7.5$ $\mathrm{ml}$ and $5.0 \mathrm{ml}$ of Klebsiella sp., respectively. D10 $=10 \mathrm{ml}$ of control.

\section{Seedling vigor index}

The maximum seedling vigor index (22.23) was observed in the A10, while the least (4.89) was observed in the control (Fig. 9). There was significant differences $(P<0.05)$ in the seed vigor index between all the bacterial inocula and the control. However, no significant difference were observed between the A5, C7.5 and B7.5. These results clearly showed the beneficial influence of the growth-promoting bacteria on rice seedling health and yield.

\section{Discussion}

The 16S rRNA results showed Bacillus cereus strain GGBSU-1, strain TL14-1, and Klebsiella variicola strain AUH-KAM-9 as the thrProteus mirabilisee identified
PGP bacteria with proven PSB capabilities. Numerous Bacillus strains express plant growth-promoting (PGP) activities and they have been used to improve growth of crops. For example, Beneduzi et al. (2008) had isolated the plant growth-promoting strain SVPR30 identified by $16 \mathrm{~S}$ rRNA gene sequence as Bacillus spp. and had been used to promote plant growth through in vivo experiments. Behera et al. (2014) reported Bacillus and Proteus strains as the most powerful and abundant PGP bacteria and improved the growth of rice species. Klebsiella sp. has also been frequently found to be associated with hospital infections (Podschun and Ullmann 1998); however, the pathogenicity of the K. variicola isolates from plants has not been determined (Rosenblueth et al. 2004), but $K$. variicola DX120E have been documented by Bashan et al. (2013) to promote sugarcane growth. 
Table 5 Effect of PSB inoculum on in vitro dry root of rice.

\begin{tabular}{|c|c|c|c|c|c|c|}
\hline \multirow[t]{2}{*}{ Inoculum } & \multicolumn{6}{|c|}{ Dry root length $(\mathrm{cm})$ on } \\
\hline & 4DAS & 5DAS & 6DAS & 2WAS & 3WAS & 4WAS \\
\hline$A / 10$ & $2.0 \pm 0.11^{\mathrm{a}}$ & $3.2 \pm 0.46^{\mathrm{a}}$ & $4.1 \pm 0.15^{a}$ & $4.8 \pm 0.10^{\mathrm{a}}$ & $6.8 \pm 0.52^{\mathrm{a}}$ & $7.3 \pm 0.03^{a}$ \\
\hline $\mathrm{A} / 7.5$ & $1.1 \pm 0.08^{b}$ & $2.6 \pm 0.15^{b}$ & $3.3 \pm 0.16^{b}$ & $4.1 \pm 0.18^{b}$ & $5.7 \pm 0.20^{b}$ & $6.1 \pm 0.04^{b}$ \\
\hline $\mathrm{A} / 5$ & $1.2 \pm 0.17^{b}$ & $2.3 \pm 0.12^{c}$ & $3.4 \pm 0.03^{b}$ & $3.9 \pm 0.36^{b}$ & $5.4 \pm 0.04^{c}$ & $5.9 \pm 0.11^{c}$ \\
\hline$B / 10$ & $0.5 \pm 0.16^{c}$ & $1.3 \pm 0.05^{\mathrm{d}}$ & $2.4 \pm 0.03^{c}$ & $3.3 \pm 0.17^{c}$ & $4.5 \pm 0.11^{d}$ & $5.0 \pm 0.32^{d}$ \\
\hline $\mathrm{B} / 7.5$ & $0.7 \pm 0.00^{c}$ & $1.0 \pm 0.06^{\mathrm{e}}$ & $2.1 \pm 0.07^{d}$ & $2.8 \pm 0.26^{d}$ & $4.4 \pm 0.40^{d}$ & $4.8 \pm 0.43^{e}$ \\
\hline$B / 5$ & $0.2 \pm 0.05^{d}$ & $1.2 \pm 0.06^{\mathrm{de}}$ & $2.4 \pm 0.06^{c}$ & $3.2 \pm 0.18^{c}$ & $4.0 \pm 0.25^{e}$ & $4.3 \pm 0.11^{f}$ \\
\hline$C / 10$ & $1.2 \pm 0.65^{b}$ & $2.0 \pm 0.31^{f}$ & $2.8 \pm 0.23^{e}$ & $3.5 \pm 0.05^{\mathrm{cb}}$ & $6.0 \pm 0.32^{f}$ & $7.0 \pm 0.09^{\mathrm{a}}$ \\
\hline $\mathrm{C} / 7.5$ & $2.3 \pm 0.00^{\mathrm{a}}$ & $2.7 \pm 0.79^{b}$ & $3.1 \pm 0.14^{b}$ & $3.5 \pm 0.05^{\mathrm{cb}}$ & $5.2 \pm 0.07^{\mathrm{cg}}$ & $5.6 \pm 0.78^{c}$ \\
\hline $\mathrm{C} / 5$ & $0.2 \pm 0.00^{d}$ & $1.0 \pm 0.06^{\mathrm{e}}$ & $1.8 \pm 0.32^{f}$ & $2.9 \pm 0.33^{d}$ & $5.0 \pm 0.35^{9}$ & $5.5 \pm 0.54^{c}$ \\
\hline $\mathrm{D} / 10$ & $0.2 \pm 0.15^{d}$ & $1.1 \pm 0.09^{d}$ & $1.4 \pm 0.90^{\mathrm{g}}$ & $2.1 \pm 0.08^{e}$ & $4.1 \pm 0.05^{\mathrm{e}}$ & $4.6 \pm 0.32^{e}$ \\
\hline
\end{tabular}

DAS = Days after sowing, WAS = Weeks after sowing. Results with similar alphabetic superscripts on same column did not differ from each other ( $p>0.05)$. A10, A7.5 and $\mathrm{A} 5.0=10 \mathrm{ml}, 7.5 \mathrm{ml}$ and $5.0 \mathrm{ml}$ of Bacillus sp., respectively. B10, B7.5 and B5.0 = $10 \mathrm{ml}, 7.5 \mathrm{ml}$ and $5.0 \mathrm{ml}$ Proteus sp., respectively. C10, C7.5 and C5.0 = $10 \mathrm{ml}, 7.5$ $\mathrm{ml}$ and $5.0 \mathrm{ml}$ of Klebsiella sp., respectively. D10 $=10 \mathrm{ml}$ of control.

Germination parameters are very effective in determining the interaction of PGP bacteria and seeds. In the present study, the Bacillus cereus strain GGBSU-1 inoculated seed showed the highest germination percentage in comparison with the Proteus mirabilis strain TL14-1, Klebsiella variicola strain AUH-KAM-9 and the control which showed delayed germination. This indicated a positive impact of the Bacillus cereus strain GGBSU-1 inocula on the rice seed germination. This positive impact had led to a fast appearance of coleoptile at 24 hours in the Bacillus cereus strain GGBSU-1 inocula compared to the control which observed delayed until 48 hours. Certain

Table 6 Effect of PSB inoculum on in vitro rice length of internode

\begin{tabular}{|c|c|c|c|c|}
\hline \multirow[t]{2}{*}{ Inoculum } & \multicolumn{4}{|c|}{ Length of internode $(\mathrm{cm})$} \\
\hline & 1WAS & 2WAS & 3WAS & 4WAS \\
\hline $\mathrm{A} / 10$ & Not present & $3.1 \pm 0.26^{\mathrm{a}}$ & $4.3 \pm 0.25^{a}$ & $5.1 \pm 0.11^{\mathrm{a}}$ \\
\hline $\mathrm{A} / 7.5$ & Not present & $2.0 \pm 0.26^{b}$ & $3.2 \pm 0.33^{b}$ & $4.1 \pm 0.56^{b}$ \\
\hline $\mathrm{A} / 5$ & Not present & $0.8 \pm 0.26^{c}$ & $2.7 \pm 0.22^{c}$ & $3.3 \pm 0.11^{c}$ \\
\hline $\mathrm{B} / 10$ & Not present & $0.3 \pm 0.23^{c}$ & $1.1 \pm 0.12^{d}$ & $2.2 \pm 0.22^{d}$ \\
\hline$B / 7.5$ & Not present & $0.0 \pm 0.03^{c}$ & $1.2 \pm 0.22^{d}$ & $1.9 \pm 0.34^{\mathrm{e}}$ \\
\hline$B / 5$ & Not present & Not present & $0.5 \pm 0.11^{\mathrm{e}}$ & $0.8 \pm 0.54^{f}$ \\
\hline$C / 10$ & Not present & $1.6 \pm 0.23^{b}$ & $3.4 \pm 0.43^{b}$ & $3.7 \pm 0.11^{c}$ \\
\hline $\mathrm{C} / 7.5$ & Not present & $1.5 \pm 0.12^{b}$ & $2.9 \pm 0.13^{c}$ & $3.2 \pm 0.44^{c}$ \\
\hline $\mathrm{C} / 5$ & Not present & $0.7 \pm 0.31^{c}$ & $2.2 \pm 0.54^{c}$ & $2.6 \pm 0.77^{d}$ \\
\hline $\mathrm{D} / 10$ & Not present & Not present & $0.3 \pm 0.56^{e}$ & $1.1 \pm 0.32^{9}$ \\
\hline
\end{tabular}

DAS $=$ Days after sowing, WAS $=$ Weeks after sowing. Results with similar alphabetic superscripts on same column did not differ from each other $(p>0.05)$. A10, A7.5 and A5.0 $=10 \mathrm{ml}, 7.5 \mathrm{ml}$ and $5.0 \mathrm{ml}$ of Bacillus sp., respectively. B10, $\mathrm{B} 7.5$ and $\mathrm{B} 5.0=10 \mathrm{ml}, 7.5 \mathrm{ml}$ and $5.0 \mathrm{ml}$ Proteus sp., respectively. C10, C7.5 and $\mathrm{C} 5.0=10 \mathrm{ml}, 7.5 \mathrm{ml}$ and $5.0 \mathrm{ml}$ of Klebsiella sp., respectively. D10 $=10 \mathrm{ml}$ of control. bacteria species such as Bacillus subtilis have been shown to significantly enhance germination parameters of mustard family and several other plant species (Wu et al. 2016). The water use efficiency of rice seeds, germination time and speed of germination were also influenced by the Bacillus cereus strain GGBSU-1, Proteus mirabilis strain TL14-1 and Klebsiella variicola strain AUHKAM-9 inoculation. This is likely as a result of the ability of these bacteria to change the seed microbiome, thereby improving germination parameters as against the control. This is consistent with the work of Gupta et al. (2012a) who observed that treatment of plants with certain PSB bacteria consequently improved germination of maize seeds.

Seed germination could be divided into three phases (Bewley 1997). As reported, phase II of rice seed germination is the stage between 20 and $50 \mathrm{~h}$ after sowing (Yang et al. 2007). In order to determine the influence of the PSBs on rice seed germination, the present study observed a faster imbibition rate in the Bacillus cereus strain GGBSU-1-inoculated seed compared to the control. This clearly showed the positive influence of the Bacillus cereus strain GGBSU-1 and its ability to influence the seed microbiome, leading to rapid cell division and early activation of enzymes such as amylase that are liable for solubilizing spare food material and deliver energy and other fundamental food material for the germinating embryo (Renu 2018).

Morphological parameters are related to plant physical and external properties. In the present study, all the bacterial inoculations were observed to improve rice seedling morphological characters such as shoot length, fresh and dry root length, internode length and length of the first leaf. However, the Bacillus cereus strain 
Table 7 Influence inoculum on number of secondary roots

\begin{tabular}{|c|c|c|c|c|c|c|c|}
\hline \multirow[t]{2}{*}{ Inoculants } & \multicolumn{7}{|c|}{ Number of secondary roots } \\
\hline & 4DAS & 5DAS & 6DAS & 7DAS & 2WAS & 3WAS & 4WAS \\
\hline$A / 10$ & 4DAS & $5 \pm 0.47^{a}$ & $9 \pm 0.47^{a}$ & $11 \pm 0.47^{\mathrm{a}}$ & $15 \pm 0.47^{a}$ & $20 \pm 0.47^{a}$ & $27 \pm 0.47^{a}$ \\
\hline$A / 7.5$ & $3 \pm 0.47^{\mathrm{a}}$ & $4 \pm 0.47^{\mathrm{a}}$ & $8 \pm 0.47^{a}$ & $9 \pm 0.47^{b}$ & $12 \pm 0.47^{b}$ & $14 \pm 0.47^{b}$ & $16 \pm 0.47^{b}$ \\
\hline $\mathrm{A} / 5$ & $1 \pm 0.47^{b}$ & $4 \pm 0.47^{\mathrm{a}}$ & $7 \pm 0.47^{b}$ & $8 \pm 0.47^{b}$ & $11 \pm 0.47^{b}$ & $14 \pm 0.47^{b}$ & $19 \pm 0.47^{c}$ \\
\hline$B / 10$ & Not present & $2 \pm 0.47^{b}$ & $7 \pm 0.47^{b}$ & $9 \pm 0.47^{b}$ & $9 \pm 0.47^{c}$ & $13 \pm 0.47^{b}$ & $16 \pm 0.47^{b}$ \\
\hline $\mathrm{B} / 7.5$ & Not present & $2 \pm 0.47^{b}$ & $7 \pm 0.47^{b}$ & $9 \pm 0.47^{b}$ & $9 \pm 0.47^{c}$ & $11 \pm 0.47^{c}$ & $15 \pm 0.47^{b}$ \\
\hline $\mathrm{B} / 5$ & $1 \pm 0.47^{b}$ & $1 \pm 0.47^{d}$ & $3 \pm 0.47^{c}$ & $5 \pm 0.47^{c}$ & $6 \pm 0.47^{d}$ & $9 \pm 0.47^{d}$ & $13 \pm 0.47^{d}$ \\
\hline$C / 10$ & $1 \pm 0.47^{b}$ & $2 \pm 0.47^{b}$ & $7 \pm 0.47^{b}$ & $9 \pm 0.47^{b}$ & $10 \pm 0.47^{d}$ & $13 \pm 0.47^{b}$ & $17 \pm 0.47^{b}$ \\
\hline $\mathrm{C} / 7.5$ & $3 \pm 0.47^{\mathrm{a}}$ & $1 \pm 0.47^{d}$ & $6 \pm 0.47^{b}$ & $6 \pm 0.47^{c}$ & $8 \pm 0.47^{c}$ & $13 \pm 0.47^{b}$ & $15 \pm 0.47^{b}$ \\
\hline $\mathrm{C} / 5$ & Not present & $3 \pm 0.47^{\mathrm{a}}$ & $4 \pm 0.47^{c}$ & $6 \pm 0.47^{c}$ & $6 \pm 0.47^{d}$ & $8 \pm 0.47^{d}$ & $11 \pm 0.47^{e}$ \\
\hline $\mathrm{D} / 10$ & Not present & Not present & $3 \pm 0.47^{c}$ & $3 \pm 0.47^{d}$ & $5 \pm 0.47^{d}$ & $7 \pm 0.47^{\mathrm{de}}$ & $9 \pm 0.47^{f}$ \\
\hline
\end{tabular}

DAS = Days after sowing, WAS = Weeks after sowing. Results with similar alphabetic superscripts on same column did not differ from each other ( $>0.05$ ). A10, A7.5 and $\mathrm{A} 5.0=10 \mathrm{ml}, 7.5 \mathrm{ml}$ and $5.0 \mathrm{ml}$ of Bacillus sp., respectively. B10, B7.5 and B5.0 = $10 \mathrm{ml}, 7.5 \mathrm{ml}$ and $5.0 \mathrm{ml}$ Proteus sp., respectively. C10, C7.5 and C5.0 = $10 \mathrm{ml}, 7.5$ $\mathrm{ml}$ and $5.0 \mathrm{ml}$ of Klebsiella sp., respectively. D10 $=10 \mathrm{ml}$ of control.

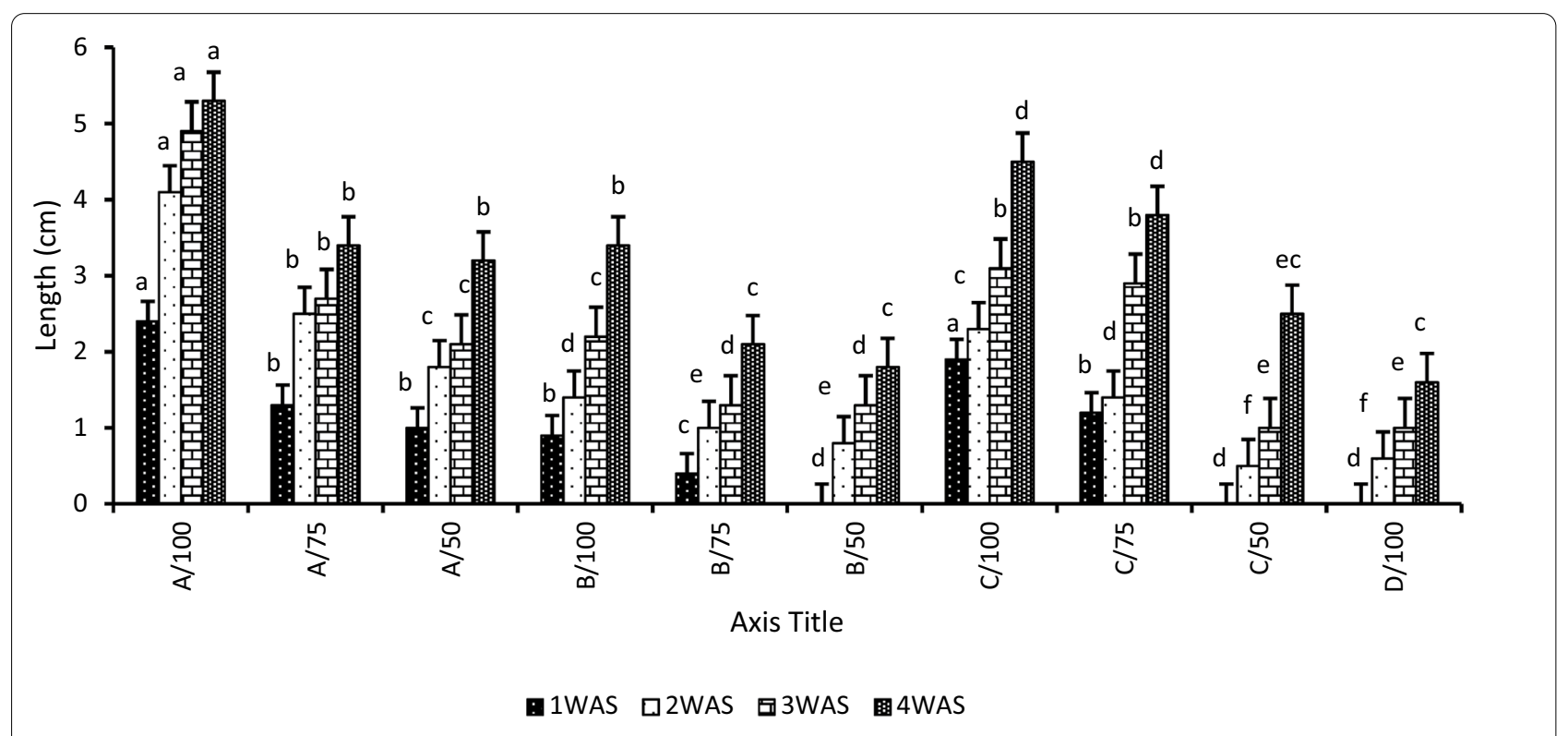

Fig. 4 Length of first leaf (WAS - weeks after sowing). Results with similar al phabets on same bars did not differ from each other ( $p>0.05)$

GGBSU-1-inoculated seed was observed to show the highest improvement than Proteus sp. and Klebsiella $s p$. inoculations. This indicates the ability of the Bacillus cereus strain GGBSU-1 to improve growth properties of rice. This may be as a result of the ability of the bacteria to produce some metabolites such as IAA and siderophores that facilitate the plant growth. According to Dey et al. (2004), IAA secreted by rhizobacteria may effectively improve root growth by stimulating plant cell elongation or division, resulting in greater root surface area, which enables the plant to access more nutrients from soils. The present study indicated that the inoculation of Bacillus cereus strain GGBSU1, Proteus mirabilis strain TL14(1) and Klebsiella variicola strain AUH-KAM-9 influence the morphological parameters of rice seedlings at different levels.

The significant increase in rice seedling secondary root observed in all the PSB bacteria-inoculated setup at all the assayed days indicates growth-promoting capabilities of the isolates. Some earlier reports have 


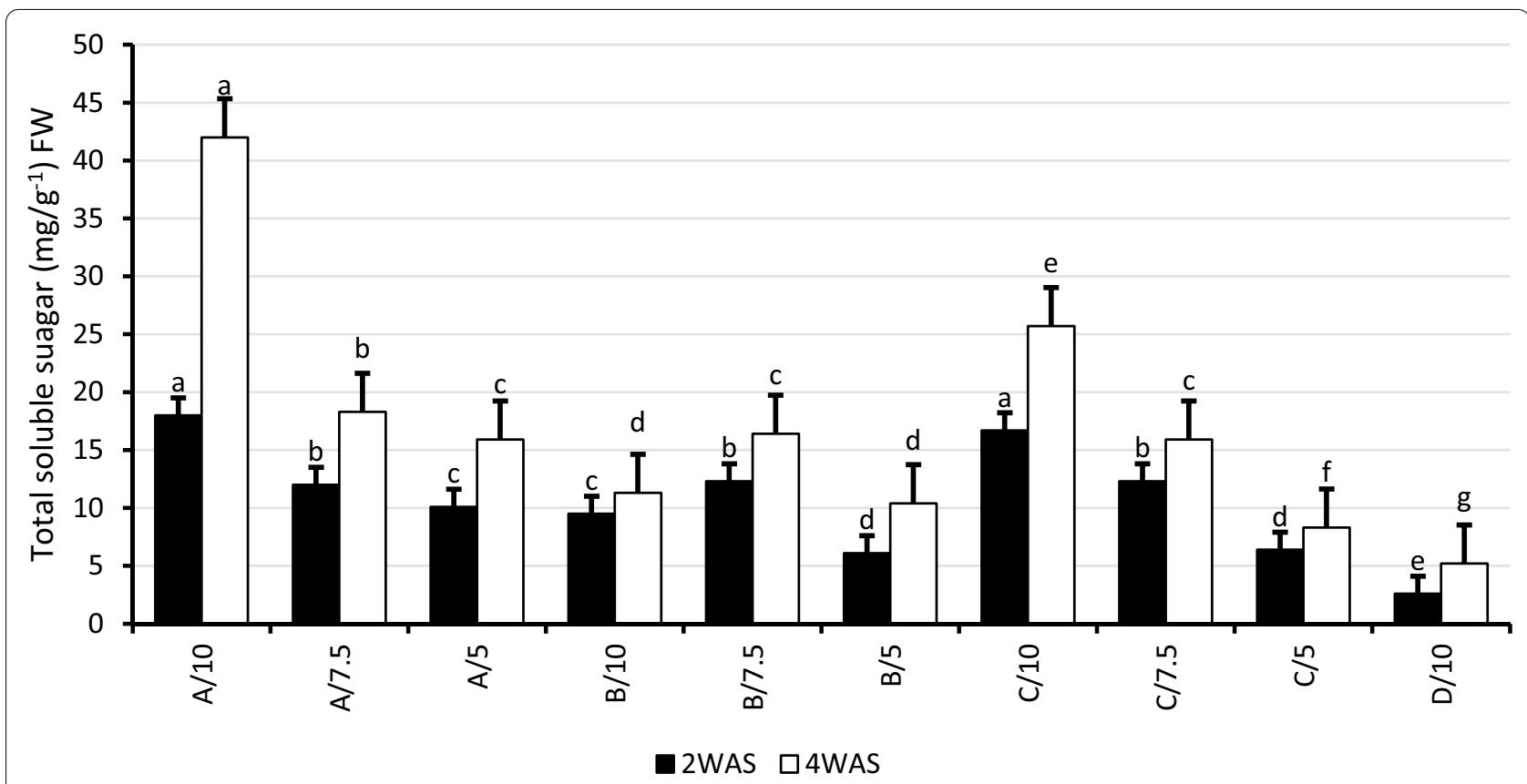

Fig. 5 Total soluble sugar contents of rice seedlings at 2 and 4 weeks after sowing. Results with similar alphabets on same bars did not differ from each other $(p>0.05)$.

Table 8 Effect of PSB inoculum on in vitro rice physiological parameters

\begin{tabular}{|c|c|c|c|c|c|c|c|c|c|c|c|c|c|c|}
\hline \multirow[t]{2}{*}{ Inoculum } & \multicolumn{2}{|c|}{$\begin{array}{l}\text { Chlorophyll-a } \\
\left(\mathrm{mg} / \mathrm{cm}^{2}\right) \mathrm{FW} \text { on }\end{array}$} & \multicolumn{2}{|c|}{$\begin{array}{l}\text { Chlorophyll-b } \\
\left(\mathrm{mg} / \mathrm{cm}^{2}\right) \mathrm{FW} \text { on }\end{array}$} & \multicolumn{3}{|c|}{$\mathrm{OLCCI}\left(\mu \mathrm{mol} / \mathrm{m}^{2}\right)$ on } & \multicolumn{3}{|c|}{$\mathrm{NLCCl}\left(\mu \mathrm{mol} / \mathrm{m}^{2}\right)$ on } & \multicolumn{3}{|c|}{$\begin{array}{l}\text { Leaf tip \% Necrosis and } \\
\text { Chlorosis on }\end{array}$} & \multirow{2}{*}{$\begin{array}{l}\text { LLA }\left(\mathrm{cm}^{2}\right) \text { on } \\
\text { 4WAS }\end{array}$} \\
\hline & 2WAS & 4WAS & 2WAS & 4WAS & 2WAS & 3WAS & 4WAS & 2WAS & 3WAS & 4WAS & 2WAS & 3WAS & 4WAS & \\
\hline$A / 10$ & 6.4 & 8.9 & 1.9 & 4.6 & 1.2 & 1.3 & 1.5 & 1.1 & 1.4 & 1.7 & ND & ND & ND & 2.0 \\
\hline$A / 7.5$ & 6.1 & 8.1 & 1.6 & 3.2 & 1.1 & 1.1 & 1.3 & 0.9 & 1.0 & 1.3 & ND & 33.3 & 25 & 0.6 \\
\hline $\mathrm{A} / 5$ & 4.5 & 6.5 & 0.6 & 1.0 & 1.1 & 1.2 & 1.3 & 1.1 & 1.2 & 1.4 & 50 & 66.6 & 50 & 0.6 \\
\hline$B / 10$ & 4.0 & 7.2 & 2.4 & 3.0 & 1.1 & 1.1 & 1.2 & 1.2 & 1.3 & 1.5 & ND & 33.3 & 50 & 0.4 \\
\hline$B / 7.5$ & 4.3 & 6.5 & 1.7 & 2.3 & 1.2 & 1.3 & 1.4 & 0.6 & 0.9 & 1.2 & 50 & 33.3 & 25 & 0.3 \\
\hline$B / 5$ & 4.1 & 5.1 & 0.8 & 1.2 & 1.1 & 1.2 & 1.3 & 0.4 & 0.7 & 1.0 & 50 & 33.3 & 50 & 0.4 \\
\hline$C / 10$ & 6.1 & 8.0 & 2.5 & 4.3 & 1.3 & 1.4 & 1.5 & 1.1 & 1.3 & 1.5 & ND & 33.3 & 25 & 0.6 \\
\hline$C / 7.5$ & 5.3 & 7.8 & 1.2 & 3.0 & 1.3 & 1.3 & 1.4 & 1.0 & 1.2 & 1.4 & ND & ND & ND & 0.3 \\
\hline $\mathrm{C} / 5$ & 4.0 & 6.5 & 0.8 & 1.0 & 1.0 & 1.1 & 1.2 & 0.6 & 0.9 & 1.3 & 100 & 66.6 & 50 & 0.3 \\
\hline $\mathrm{D} / 10$ & 2.3 & 4.1 & 0.3 & 0.7 & 0.6 & 0.8 & 1.0 & 0.3 & 0.7 & 1.0 & 100 & 66.6 & 76 & 0.15 \\
\hline
\end{tabular}

identified certain bacteria as effective in improving plant root length, thereby improving the uptake of water and nutrient which consequently increase seedling growth and yield morphology (Walker et al. 2012) as observed in the present study. This is consistent with the work of (Zamioudis et al. 2013) who observed that under the influence of certain beneficial bacteria, the root number and structure of Arabidopsis seedlings were improved.
Plant productivity can be accessed using total sugars. The increase in total soluble sugar content observed in rice seedlings at 2 and 4WAS indicated the important role of the inoculum in improving rice seedling sugar content, which consequently plays an important role in plant metabolism, growth and hormone signaling (Rolland et al. 2002). Seedlings with high sugar contents may signify improved growth and yield. According to Lucas et al. (2014), different bacterial strains modify different 


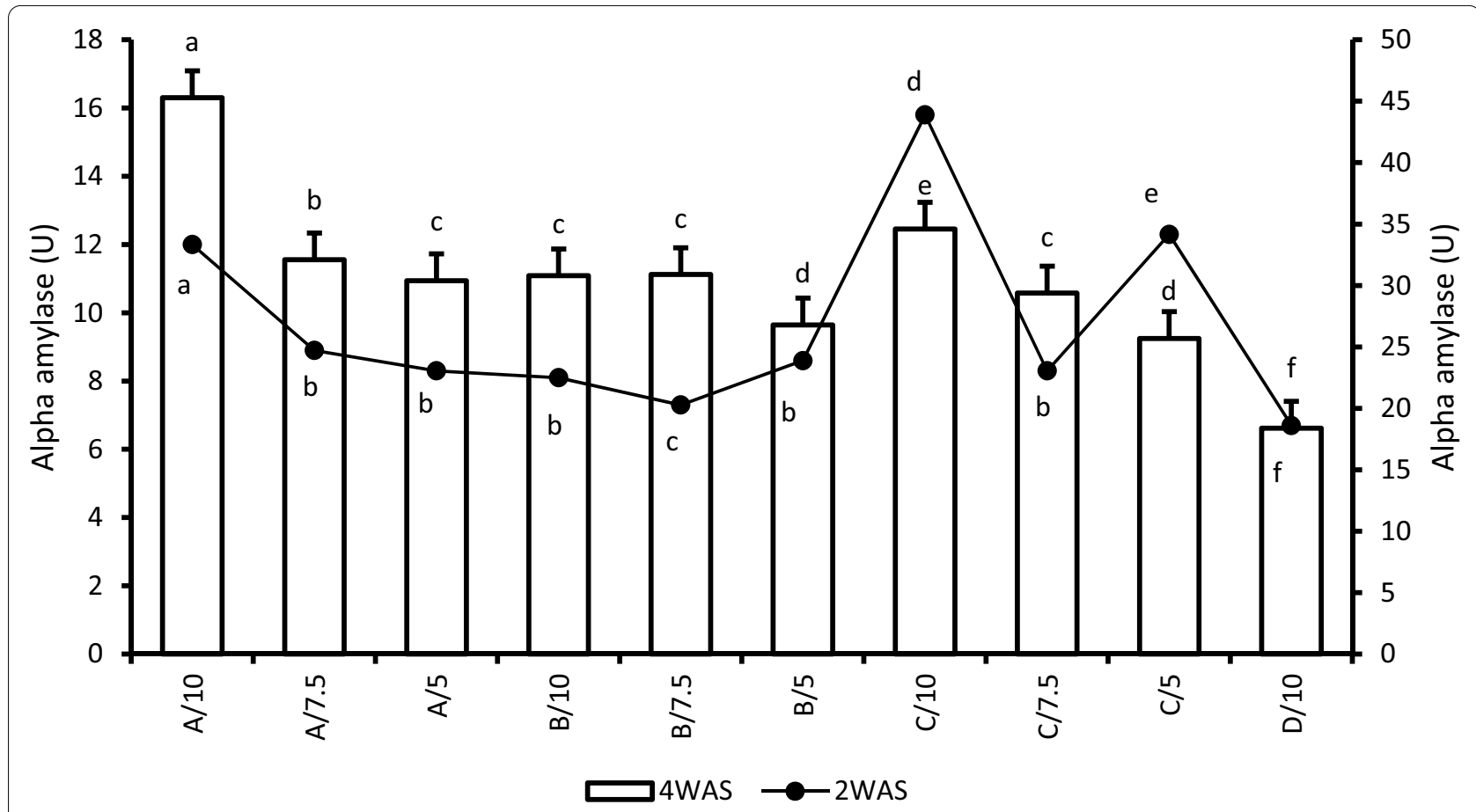

Fig. 6 Leaf tip necrosis and chlorosis

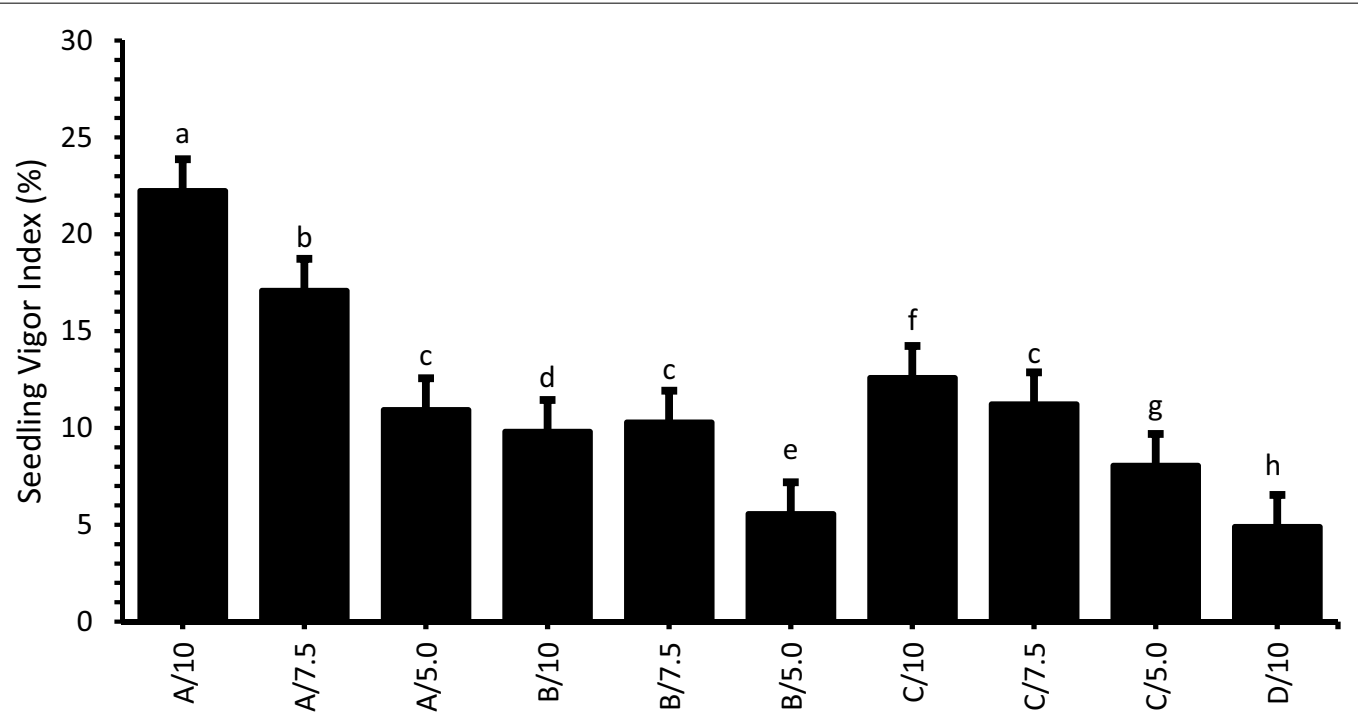

Fig. 7 Leaf area measurement using leaf-IT

innate plant mechanism such as total soluble sugar at different levels. Garcia-Cristobal et al. (2015) also reported the ability of a Chryseobacterium strain to enhance total sugar level in pathogen-stressed rice plants.

The increase in chlorophyll levels is considered to be a parameter indicating increase in photosynthetic capacity and consequently increase plant yield and vigor (Bashan et al. 2006). The increase in Chlorophyll-a (Chl a) and b (Chl b) contents and chlorophyll index content (CCI) of rice seedlings at 2 and 4WAS was significant in influencing the bacteria. Bacterial strains can improve plant photosynthetic rate that benefit plant growth (Chaves et al. 2003). Since lack of chlorophyll, damaged roots and hormonal imbalances are known to result in chlorosis 




Fig. 8 Alpha amylase at week 2 and 4. Results with similar alphabets on same bars (or line graph) did not differ from each other ( $p>0.05$ ).

and eventual necrosis of seedlings, the lack of chlorosis and necrosis observed in the Bacillus cereus strain GGBSU-1 and Salmonella enterica sub. arizonae strain DSM9386 inocula indicate the morphological influence of the bacteria in rice seedling. This may be attributed to that the inoculum improved the seedling hormone levels in the Bacillus cereus strain GGBSU-1 and Salmonella enterica sub. arizonae strain DSM9386-inoculated seeds. The increase in leaf area in the bacteria-inoculated seeds as against the control can be linked to the beneficial influence of the bacteria on seedling enzymes. According to Ehrlich (1990), the major role of bacteria in seed is to stimulate plant growth through production of phytohormones.

The improved levels of $\alpha$-amylase at 2 and 4WAS in the PSB inoculated seeds may likely be as a result of the improved photosynthetic capacity and enzymes metabolism caused by the PGP nature of the isolates. Since $\alpha$-amylase has been shown to be very important in initiating starch degradation in cereal grains (Beck and Ziegler 1989), higher $\alpha$-amylase showed higher starch degradation and higher energy for further development and metabolic activities.

The improved fresh and dry shoot weight observed in the inoculum-induced rice seedling showed the plant growth-promoting capabilities of the isolates. The higher shoot weight may consequently signify improved growth and yield of the test plant. This result is consistent with the work of Sarma and Saikia (2014) who suggested that Bacillus lentimorbus and Pseudomonas aeruginosa strains enhanced seedling height and shoot weight of Vigna radiata plants under drought stress.

Significantly higher levels of seed vigor are requisite in high seed health and improved seedling yield. The effect of the bacteria inocula on rice seedling vigor showed the beneficial influence of the growth-promoting bacteria on rice seedling health and yield. The present result agreed with the work of Yadav et al. (2016), who investigated

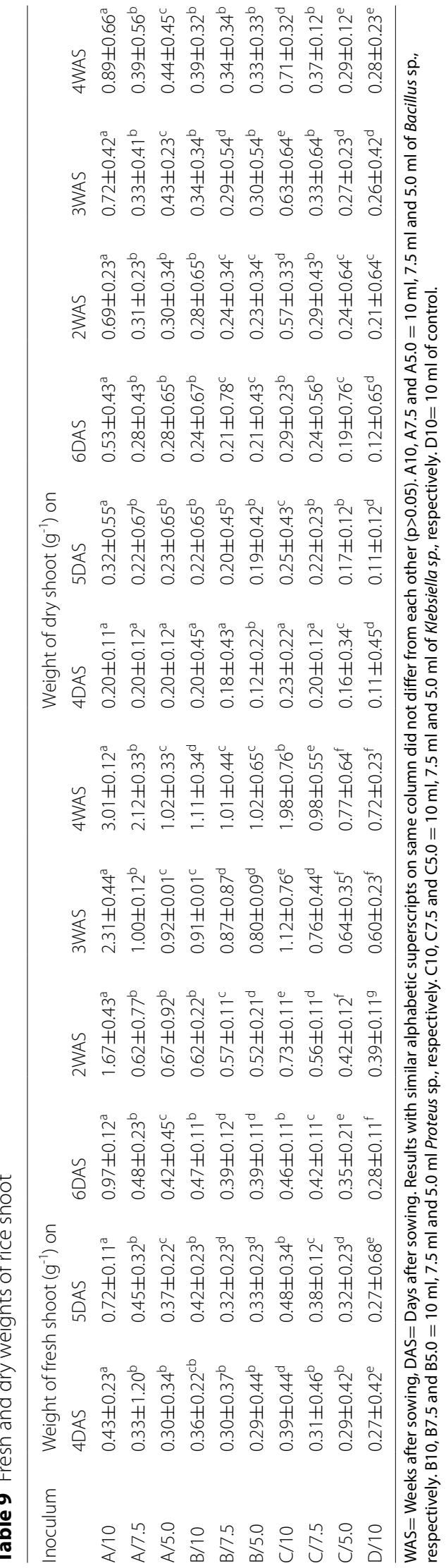




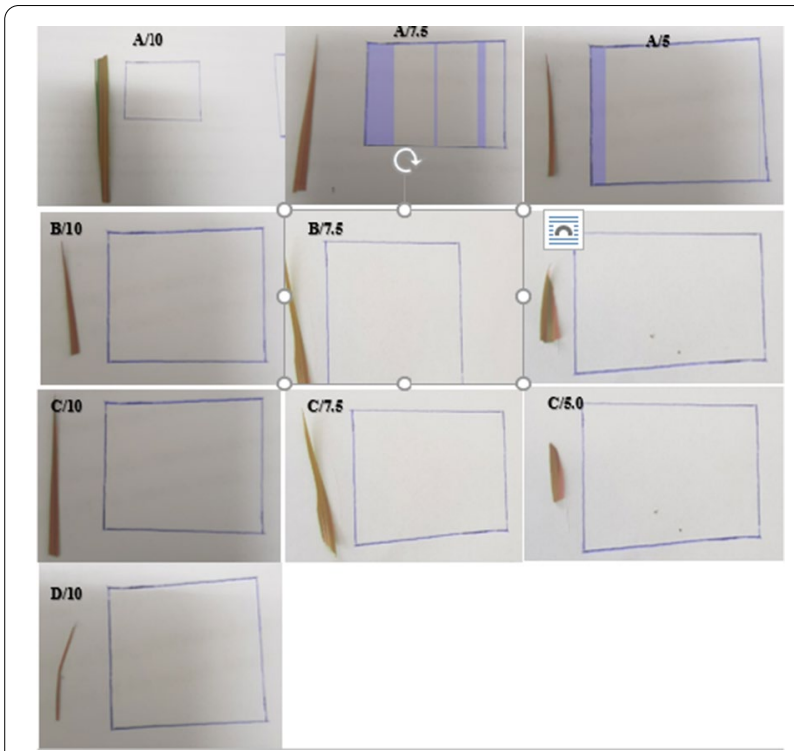

Fig. 9 Seedling vigor index. Results with similar alphabets on same bars did not differ from each other ( $p>0.05$ ).

the influence of endophytic fungi on plant growth and seed vigor of green gram seeds. Furthermore, Singh et al. (2010) has also reported improved seed germination and seedling vigor upon inoculation with plant growth-promoting rhizobacteria on lentil seeds.

\section{Conclusion}

The present study investigated the application of three distinct phosphate solubilizing bacteria with plant growth-promoting capabilities that were previously isolated from ferruginous soils and humus soil as a trial to investigate the growth and yield response of rice seeds. Results of this study showed that bacteria-inoculated rice had significant growth and yield properties compared to the un-inoculated setup. Also, the concentration of the inoculum was observed to be directly proportional to the improving growth and yield properties. The three bacteria showed different levels of growth and yield properties on rice seedling. The setup inoculated with Bacillus cereus strain GGBSU-1 (A) was observed to show the highest yield effect on the rice seeds, followed by Klebsiella variicola strain AUH-KAM-9 (C), while Proteus mirabilis strain TL14-1 (B) had the least rice growth parameters. Since these bacteria proved effective in improving growth and yield parameters of rice in an in vitro setup, further studies should be conducted to trail the in vivo effectiveness of these bacteria in phosphorusdeficient soils such as ferruginous soils. This would provide a sustainable way of enhancing crop production and toxic metals remediation.

\section{Appendix}

See Figs. 10, 11, 12, 13, 14, 15, 16, and 17.

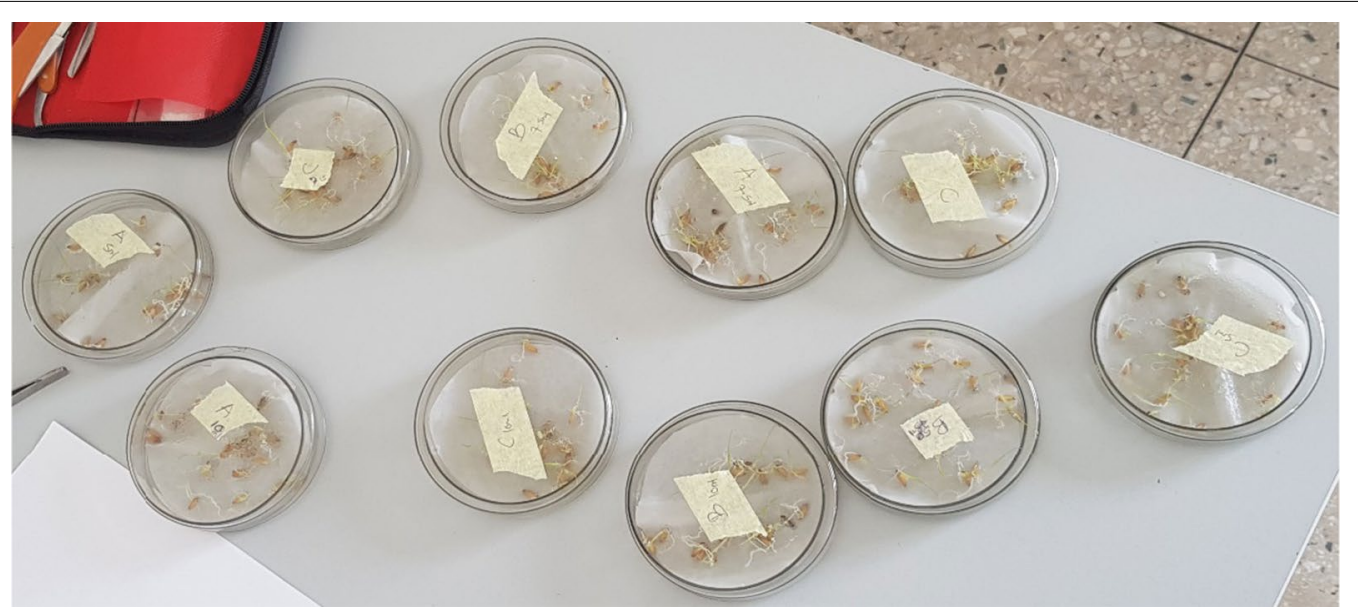

Fig. 10 Showing In vitro germination of rice after inoculation with the three PSBs at 2DAS. DAS= Days after sowing, $A=B$ acillus sp., $B=$ Proteus $s p$., $\mathrm{C}=$ Klebsiella sp., $\mathrm{D}=$ Control. 


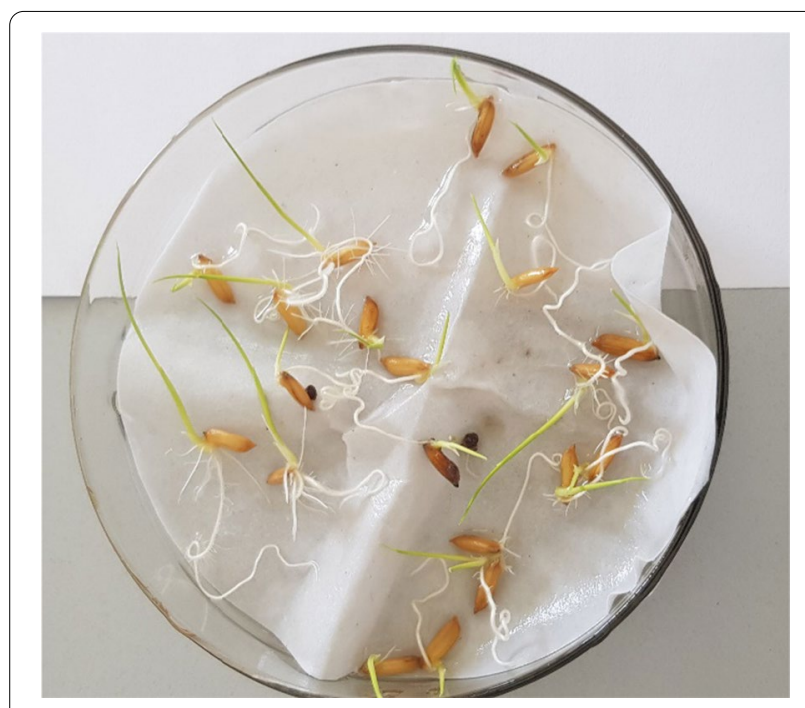

Fig. 11 Showing a sample of In vitro growth of rice after inoculation with PSB at 3DAS. DAS= Days after sowing.

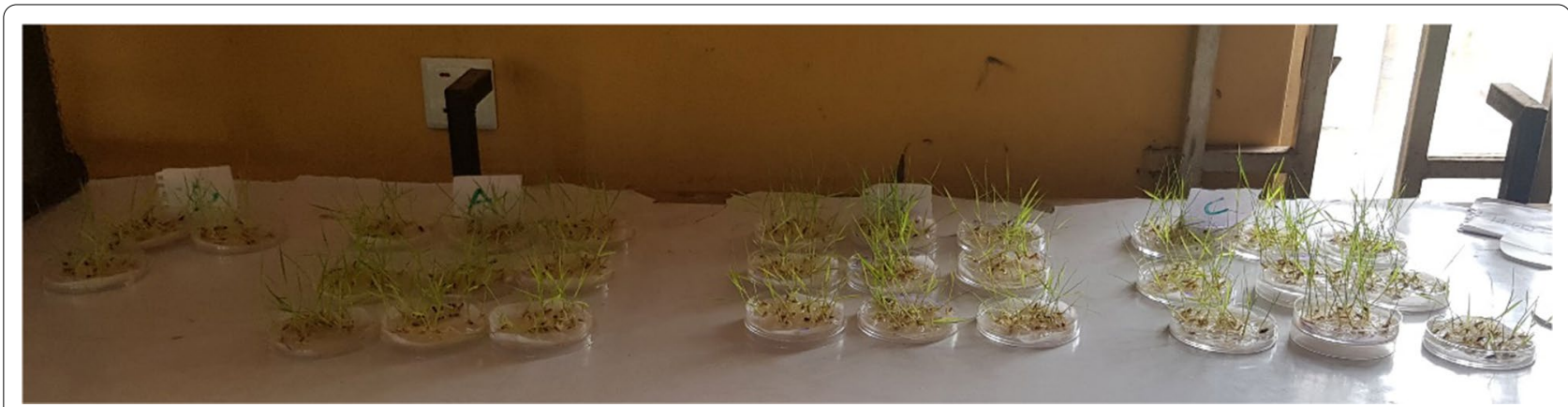

Fig. 12 In vitro growth of rice after inoculation with the three PSBs at 5DAS. DAS= Days after sowing, $\mathrm{A}=$ Bacillus sp., $\mathrm{B}=$ Proteus sp., $\mathrm{C}=$ Klebsiella sp., $\mathrm{D}=$ Control.

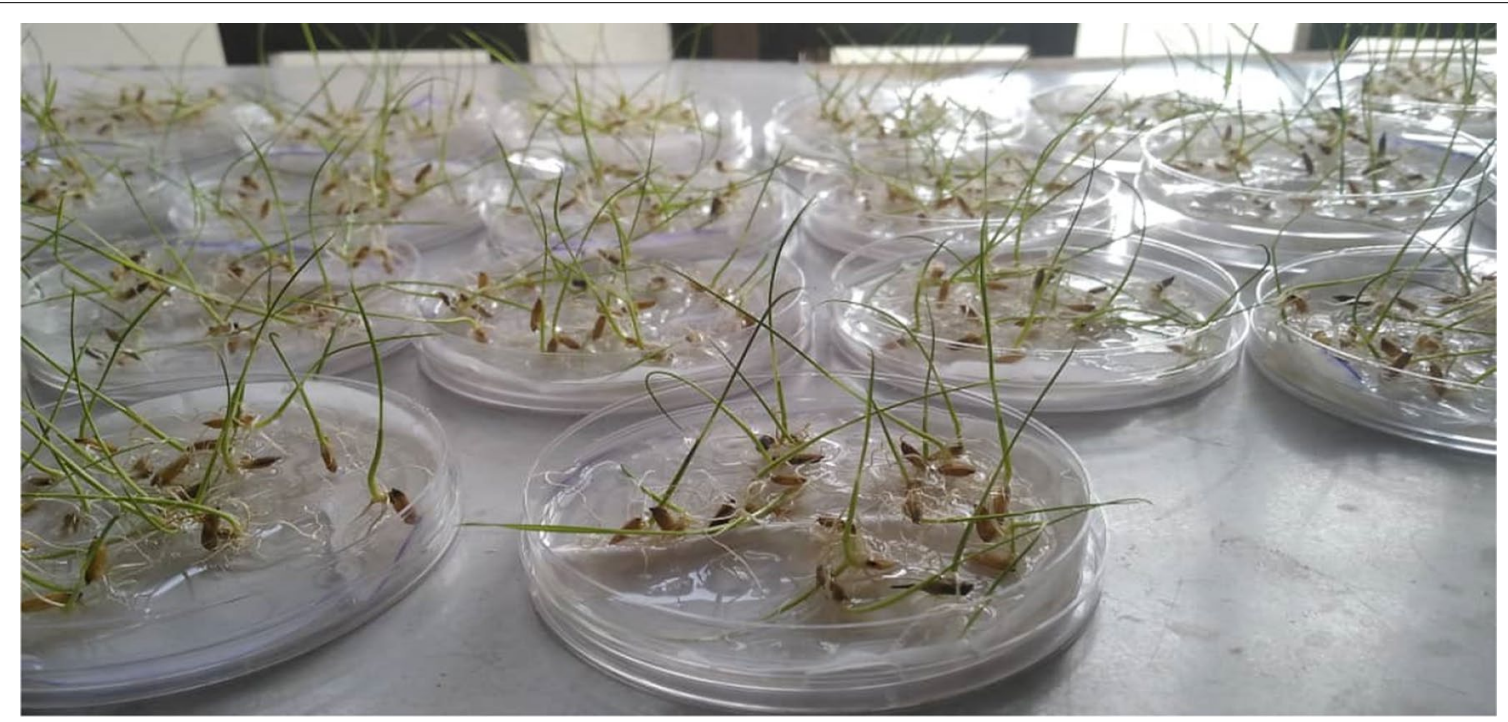

Fig. 13 In vitro growth of rice after inoculation with the three PSBs at 6DAS. DAS= Days after sowing. 


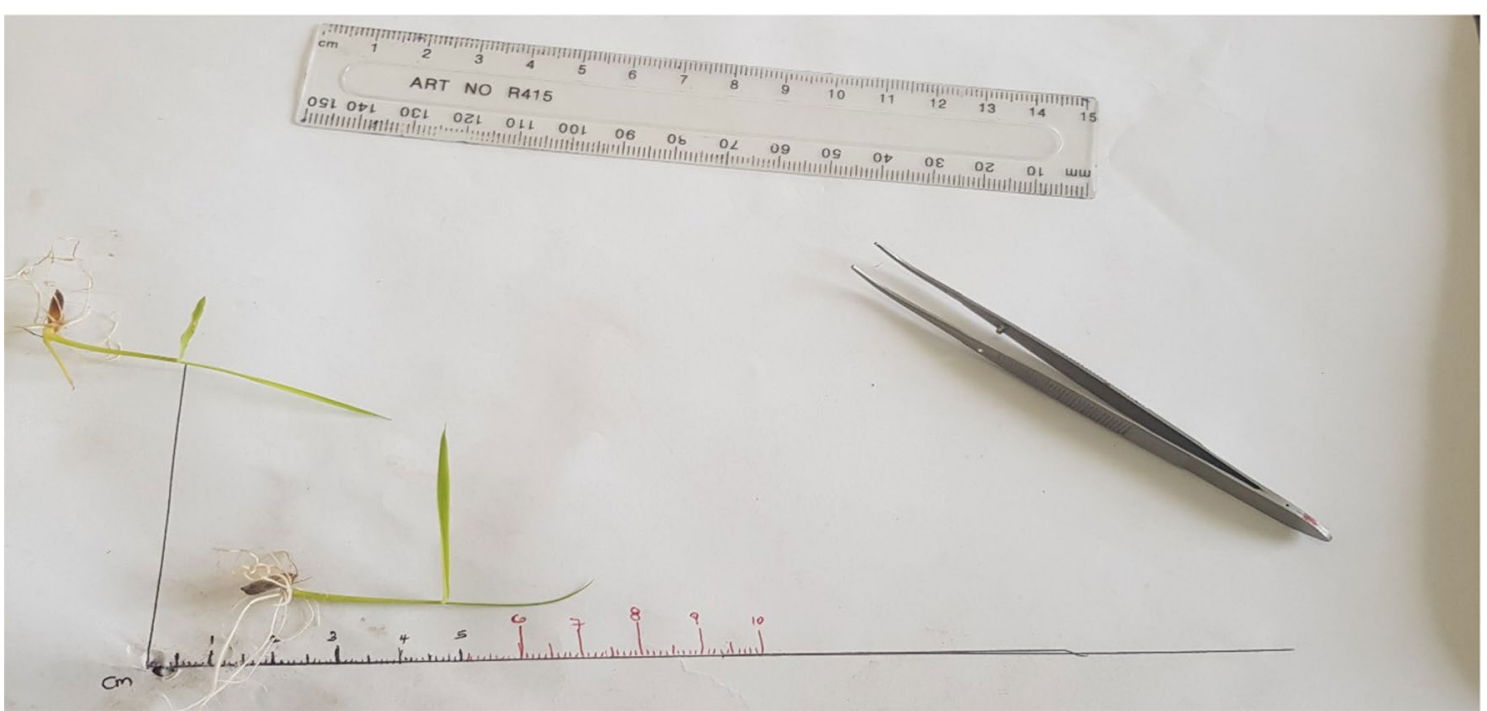

Fig. 14 Measurement of germinating seedling using a transparent ruler on a calibrated white paper.

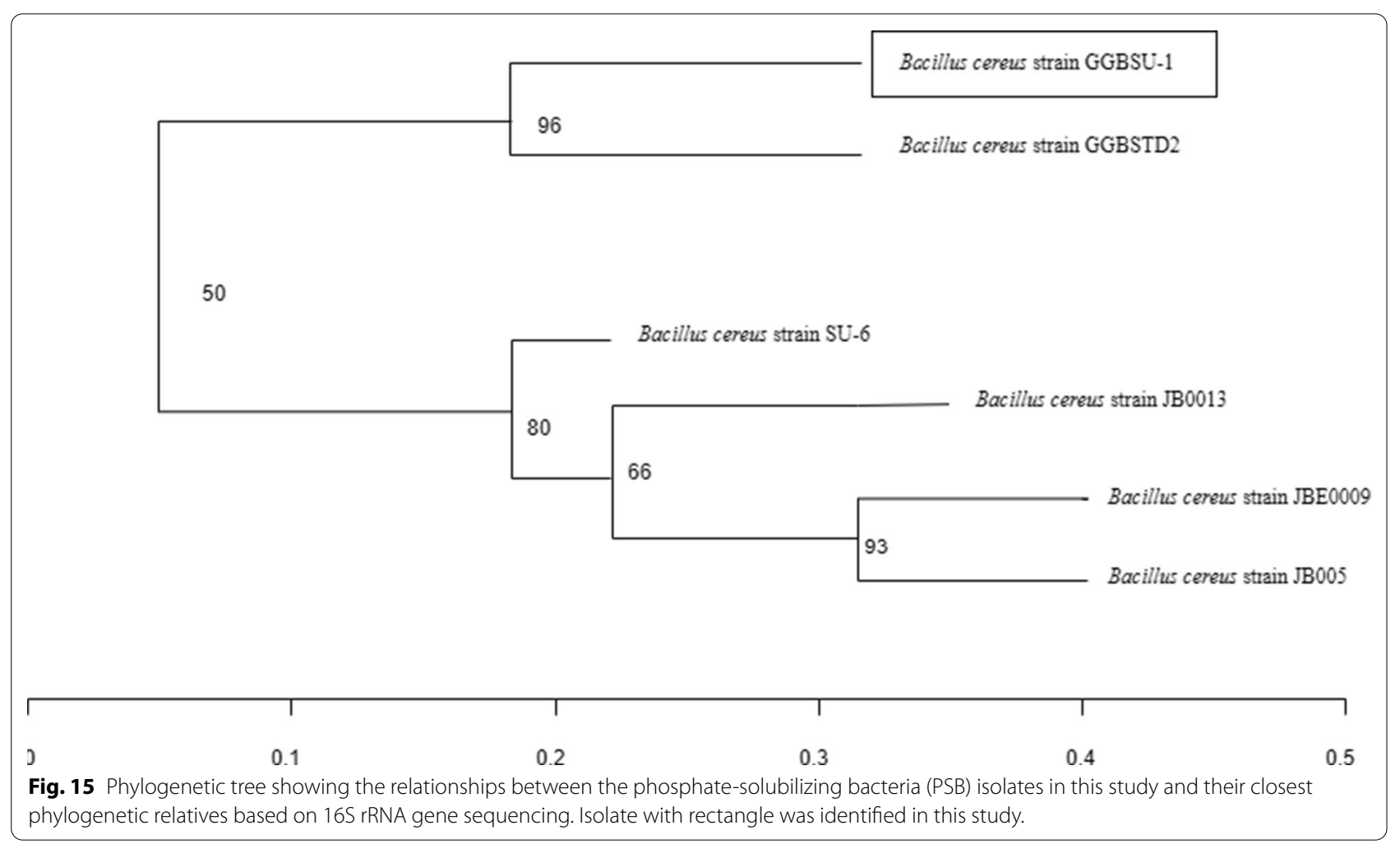



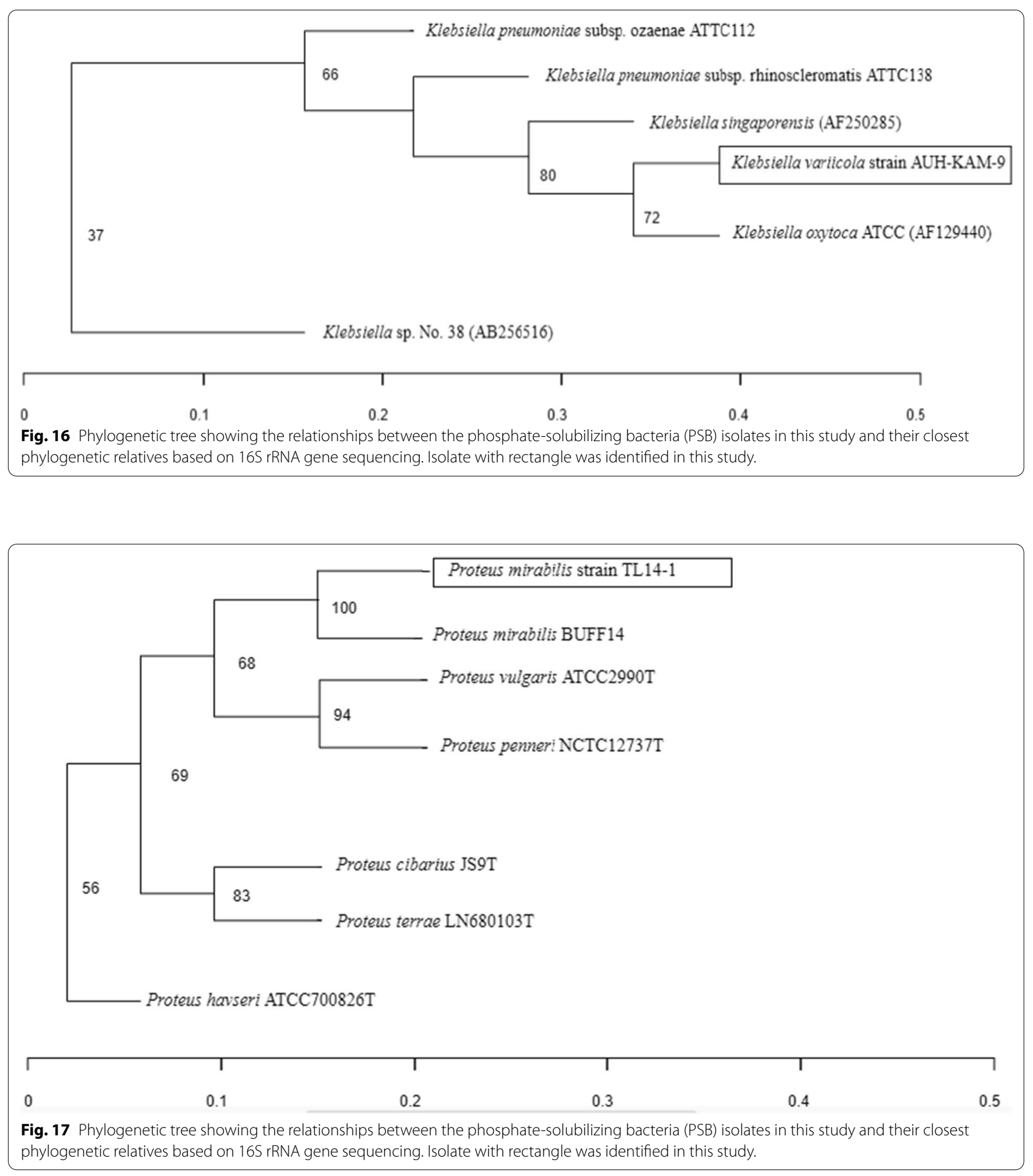


\section{Abbreviations}

NiS: Non-inoculated seed; BiS: Bacillus sp. inoculated seed; PiS: Proteus sp. inoculated seed; KiS: Klebsiella sp. inoculated seed; PGPR: Plant growth-promoting rhizobacteria; PSB: Phosphate-solubilizing bacteria; WAS: Week after sowing; DAS: Day after sowing; OL: Old leaf; CCl: Chlorophyll content index; NL: New leaf; LLA: Largest leaf area; FW: Fresh weight; APC: Appearance of coleoptile; WUE: Water use efficiency; GTM: Germination time; SGM: Speed of germination; SV: Seed vigor; Chl a: Chlorophyll-a; Chl b: Chlorophyll-b.

\section{Acknowledgements}

The researchers are grateful to the Department of Plant Biology and Biotechnology, University of Benin, Edo State-Nigeria and the Department of Biological Sciences, Admiralty University of Nigeria, Delta State-Nigeria for the facilities. The mentorship and efforts of my supervisor, Beckley Ikhajiagbe, Ph.D., FIPMD, of the Department of Plant Biology and Biotechnology during the course of the study is very much appreciated. I also acknowledge the efforts of Prof. Sanusi Gaya Muhammad, Deputy Director training at Center for Dryland Agriculture, Bayero University, Kano, Kano State-Nigeria. The advices of Prof. Anoliefo and Prof. JK Mensah are well appreciated.

\section{Authors' contributions}

MSI and BI designed the study, MSI carried out the research under the supervision of BI. MSI carried out the statistical analysis and interpretation of data. MSI wrote the first draft. Bl edited the final draft of the manuscripts. Both authors read and approved the final manuscript.

\section{Funding}

No funding was provided from any external source for the research. The research was sponsored by the authors.

\section{Availability of data and materials}

The datasets generated and/or analyzed during the current study are included in this published manuscript.

\section{Declarations}

\section{Ethics approval and consent to participate}

Not applicable

\section{Consent for publication}

Consent is given for publication of this manuscript when accepted.

\section{Competing interests}

The authors declare no conflicts of interests.

\section{Author details}

${ }^{1}$ Department of Biological Sciences, Admiralty University of Nigeria, Ibusa, Delta State, Nigeria. ${ }^{2}$ Department of Plant Biology and Biotechnology, University of Benin, Benin City, Edo State, Nigeria.

Received: 5 October 2020 Accepted: 21 March 2021

Published online: 07 April 2021

\section{References}

Abdul-Baki A, Anderson J (1973) Vigour determination in soybean seeds by multiple criteria. Crop Sci 113:630-633

Adnan M, Zahir S, Fahad S, Muhammad A, Mukhtar A, Imtiaz A (2018) Phosphate solubilizing bacteria nullify the antagonistic effect of soil calcification on bioavailability of phosphorus in alkaline soils. Sci Rep 7:1613-1623

Ajala AS, Gana A (2015) Analysis of challenges facing Rice processing in Nigeria. J Food Process 6(89):36-73

Alexandratos N, Bruinsma J (2012) World agriculture towards 2030/2050: THe 2012 revision. ESA Working paper No. 3-12. Rome, FAO

Alika J (2006) Statistics and research methods, 2nd edn. Ambik Press, Benin City, p 369

Anumalla M, Mallikarjuna B, Annamalai A, Jauhar A (2019) Tolerance of iron deficient and toxic soil conditions in rice. Plants. 8(2):31-39
Archana R, Sujit S, Girish J (2017) Physiological parameters leaf area index, crop growth rate, relative growth rate and net assimilation rate of different varieties of rice grown under different planting geometries and depths in SRI. Int J Pure Appl Biosci 5(1):362-367

Arnon D (1949) Copper enzymes in isolated chloroplast Polyphenol Oxidase in Beta vulgaris. Plant Physiol 24:1-15. https://doi.org/10.1104/pp.24.1.1 Association of official seed analysts (AOSA, 2000) Rules for testing seeds. In: Proceedings of the Association of Official Seed Analysts, 60(2): 39

Balkar S (2013). Isolation and characterization of plant growth promoting rhizobacteria (PGPR) from turmeric (curcuma longa L.). A thesis submitted in partial fulfilment of the requirements for the degree of Master of Science in the department of microbiology. College of forestry, Nauni Solan, India

Bashan Y, Gopal M, Fahad S (2006) Increase in auxiliary photoprotective photosynthetic pigments in wheat seedlings induced by Azospirillum brasilense. Biol Fertil Soils 42(1):279-285

Bashan Y, Kamnev AA, de-Bashan LE (2013) Tricalcium phosphate is inappropriate as a universal selection factor for isolating and testing phosphatesolubilizing bacteria that enhance plant growth: a proposal for an alternative procedure. Biol Fetil Soils 49:465-479

Beatrice B, Sascha P, Silke R, Kristin D, Sebastian F, Helmut J, Matthias B (2018) Successful formulation and application of plant growth-promoting Kosakonia radicincitans in Maize cultivation. BioMed Res Int. https://doi. org/10.1155/2018/6439481

Beck E, Ziegler P (1989) Ann Rev Plant Phys Plant Mol Biol 40: 95-117

Behera BC, Singdevsachan SK, Mishra RR, Dutta SK, Thatoi HN (2014) Diversity, mechanism and biotechnology of phosphate solubilising microorganism in mangrove: a review. Biocatal Agric Biotechnol 3(2):97-110

Beneduzi A, Peres D, Vargas L, Bodanese-Zanettini M, Passaglia L (2008) Evaluation of genetic diversity and plant growth promoting activities of nitrogen-fixing bacilli isolated from rice fields in South Brazil. Appl Soil Ecol 39(3):311-320

Beneduzi A, Moreira F, Costa P, Vargas L, Lisboa B, Favreto R, Baldani J, Passaglia L (2013) Diversity and plant growth promoting evaluation abilities of bacteria isolated from sugarcane cultivated in the South of Brazil. Appl Soil Ecol. 63: 94-104. https:/doi.org/https://doi.org/10.1016/j.apsoil.2012. 08.010

Bewley JD (1997) Seed germination and dormancy. Plant Cell 9:1055-1066

Chaves M, Pereira J, Maroco J (2003) Understanding plant response to drought-from genes to the whole plant. Funct Plant Biol 30:1-26

Cho DY, Ponnamperuma FN (1971) Chemistry of submerged soils. Soil Sci 112:184-194

Daramola B (2005) Government policies and competitiveness of Nigerian rice economy, Paper presented at the workshop on rice policy and food security in Sub-Saharan Africa, organized by WARDA, Cotonou, Republic of Benin

Dey R, Pal K, Bhatt D, Chauhan S (2004) Growth promotion and yield enhancement of peanut (Arachis hypogaea L.) by application of plant growthpromoting rhizobacteria. Microbiol Res 159 (4): 371-394. https:/doi. org/https://doi.org/10.1016/j.micres.2004.08.004

Doyou ED, Rakoto B, Zokpodo BL (2017) Physical behavior of andosols under different levels of mechanization: case of malagasy highlands. Int Res J India 2(7):11

Ehrlich HL (1990) Geomicrobiology, 2nd edn. Dekker, New York

Etesami H, Mirsyed H, Hosseini HA, Alikhani L, Mohammadi L (2014) Bacterial biosynthesis of 1-aminocyclopropane-1- carboxylate (ACC) deaminase and indole-3-acetic acid (IAA) as endophytic preferential selection traits by rice plant seedlings. J Plant Growth Regul 33:654-670

Garcia-cristobal J, Garcia-Villaraco A, Ramos B, Gutierrez-Manero J, Lucas J (2015) Priming of pathogenesis related-proteins and enzymes related to oxidative stress by plant growth promoting rhizobacteria on rice plants upon abiotic and biotic stress challenge. J Plant Physiol 188:72-79

Gupta M, Kiran S, Gulati A, Singh B, Tewari R (2012a) Isolation and identification of phosphate solubilizing bacteria able to enhance the growth and aloin-a biosynthesis of Maize. Microbiol Res 167(6): 358-363. https:/doi. org/https://doi.org/10.1016/j.micres.2012.02.004

Gupta M, Kiran S, Gulati A, Singh B, Tewari R (2012b) Isolation and identification of phosphate solubilizing bacteria able to enhance the growth and aloina biosynthesis of Aloe barbadensis Miller. Microbiol Res 167(6): 358-363. https:/doi.org/https://doi.org/10.1016/j.micres.2012.02.004 
Gyaneshwar P, Kumar G, Parekh L, Poole P (2002) Role of soil microorganisms in improving P nutrition of plant. Plant Soil J 245:83-93

Ikhajiagbe B, Ohanmu EO (2019) Growth and yield assessment of rice (Oryza sativa) after rhizo-inoculation with selected plant growth-promoting rhizobacteria in a ferric ultisol. Studia Universitatis "Vasile Goldiş", Seria Ştiințele Vieții. 29(3): 134-143

Ikhajiagbe Beckley, Geoffrey OA, Edokpolor OO, Gloria OO, Thomas U (2017) Investigating plant growth and physiological response to soil wetting with grey water under different shade regimes: A case of flutedpumpkin (Telfairia occidentalis). Electron J Polish Agric Univ 20(4):44-49

International Rules for Seed Testing, International Seed Testing Association (ISTA, 2005), Besserrsdorf, Switzerland

Ivy M, Chandrima B, Shayantan M, Dhritiman D, Somesh C, Ujjal K, Abhrajyoti G (2018) Effective rhizoinoculation and biofilmformation by arsenic immobilizing halophilic plant growth promoting bacteria (PGPB) isolated from mangrove rhizosphere: A step towards arsenic rhizoremediation. Sci Total Environ 610-611: 1239-1250

Jean-Francois L, Yi Z, Aradhana K, Tomas B, Carsten G, Jesper H, Henning F, Kaare H (2018) Imbibition in plant seeds. Physics.bio-ph, Pp, p 180

Joshis X, Cho C, Racz G, Chang C (2007) Chemical retardation of phosphate diffusionin an acid soil as affected by liming Nutr. Cycl. Agroecosys. 64:213-224

Julian S, Giso P, Holger K (2017) Leaf-IT: An android application for measuring leaf area. Ecol Evol 7: 9731-9738.

Kennedy G, Burlingame B, Nguyen VN (2002) Nutritional contribution of rice and impact of biotechnology and biodiversity in rice-consuming countries. Proceeding of the 20th session of the international rice commission. Bangkok, Thailand: Food and Agriculture Organization

Krishnaswamy V, Seshu DV (1990) Germination after accelerate aging and associated characters in rice varieties. J Seed Sci Technol 18(1):147-15

Kumar S, Stecher G, Li M, Knyaz C, Tamura K (2018) MEGA X: molecular evolutionary genetics analysis across computing platforms. Mol Biol Evol 35:1547-1549

Lowry O, Rosebrouch N, Farr A (1951) Randall R (1951) Protein measurement with the folin phenol reagent. J Biol Chem 193(1):265-275

Lucas J, Garcia-Cristobal J, Bonilla A, Ramos B, Gutierrez-Manero J (2014) Beneficial rhizobacteria from rice rhizosphere confers high protection against biotic and abiotic stress including systematic resistance in rice seedlings. Plant Physiol Biochem 82:44-53

Maclean J, Dawe DC, Hardy B, Hettel GP (2002) Rice almanac: source book for the most important economic activity on earth. CABI Publishing, Wallingford

Mamta M, Rahi P, Pathania V, Gulati A, Singh B, Bhanwra R, Tewari R (2010) Stimulatory effect of phosphate-solubilizing bacteria on plant growth, Stevioside and Rebaudioside a contents of Stevia rebaudiana Bertoni. Appl Soil Ecol. 46(2): 222-229. https:/doi.org/https://doi.org/10.1016/j. apsoil.2010.08.008

Maxwell K, Johnson G (2000) Chlorophyll fluorescence: a practical guide. Journal of Experimental Botany. 51:659-668. https://doi.org/10.1093/ jexbot/51.345.659

McFarland J, Nephelometer J (1944) An instrument for media used for estimating the number of bacteria in suspensions used for calculating the opsonic index and for vaccines. J Am Med Assoc 14:1176-8

Mondala D, Islama M, Hoquea M, Hossaina M, Islama M, Hossina M, Ahsan S (2016) Isolation and screening of potential phosphate solubilizing bacteria (PSB) from tidal saline soils of Bangladesh. Oct J Environ Res 4(3):198-207

Musa SI, Ikhajiagbe B (2020) Screening bacterial isolates for phosphate Solubilizing capability in a ferruginous ultisol in Benin City, Edo State Nigeria. Bayero J Pure Appl Sci. 12(2) (in press). https://doi.org/https://doi.org/10. $1101 / 2020.09 .30 .320952$

Nelson N (1944) A photometric adaptation of the Somogyis method for the determination of reducing sugar. Anal Chem 3:426-428

Nye P, Greenland D (1961) Changes in the soil after clearing tropical forest 21(1): 101-112

Obayelu S (2015) The role of rock-phosphate-solubilizing fungi and vesiculararbuscular mycorrhiza (VAM) in growth of wheat plants fertilized with rock phosphate. World J Microbiol Biotechnol 14:211-218

Ojo EO, Adebayo PF (2012) Food security in Nigeria: an overview. Eur J Sustain Dev 1(2):199-222
Podschun R, Ullmann U (1998) Klebsiella spp. as nosocomial pathogens: epidemiology, taxonomy, typing methods, and pathogenicity factors. Clin Microbiol Rev 11:589-603

Production quantity of rice. UN food and Agriculture organization, corporate statistical database (FAOSTAT, 2020)

Renu J (2018) Role of enzymes in seed germination. Int J Creative Res Thoughts 6(2):2320-2882

Rolland F, Moore B, Jen S (2002) Sugar sensing and signaling in plants. The Plant Cell, pp S185-S205

Rosenblueth M, Martínez L, Silva J, Martínez-Romero E (2004) Klebsiella variicola, a novel species with clinical and plant associated isolates. Syst Appl Microbiol 27:27-35

Saitou N, Nei M (1987) The neighbor-joining method: a new method for reconstructing phylogenetic trees. Mol Biol Evol 4:406-425

Saneya B, Muhammad A (2017) Plant growth promoting rhizobacteria (PGPR) reduces application rates of fertilizers in Chili (Capsicum frutescens $L$.) cultivation. J Horticult 4(4): 1-4

Sankar G, Selvaraju M (2015) Growth and biochemical contents of Cowpea (Vigna unguiculata L.) on the application of zinc. World Scientific News 16:73-83

Sarma R, Saikia R (2014) Alleviation of drought stress in mung bean by strain Pseudomonas aeruginosa GGRK21. Plant Soils. 377:111-126

Sharma S, Sayyed RZ, Trivedi MH, Gobi TA (2013) Phosphate solubilizing microbes: sustainable approach for managing phosphorus deficiency in agricultural soils. Springerplus 2:587-600

Shiferaw B, Prasanna B, Hellin J, B-anziger M (2011) Crops that feed the world 6. Past successes and future challenges to the role played by maize in global food security. Food Security. 3(3): 307-327

Singh AV, Prasad B, Shah S (2010) Screening Plant growth promotory rhizobacteria for improving seed germination and seedling vigor of lentil (Lens culinaris Medik). Environ Ecol 28:2055-2058

Sivasankari B, Anandharaj M (2014) Isolation and molecular characterization of potential plant growth promoting Bacillus cereus GGB3TD1 and Pseudomonas spp. GGBSTD3 from vermisources. Adv Agric. Article ID 248591, 13

Tamura K, Nei M, Kumar S (2004) Prospects for inferring very large phylogenies by using the neighbor-joining method. Proc Natl Acad Sci (USA) 101:11030-11035

Udemezue JC (2018) Analysis of Rice production and consumption trends in Nigeria. J Plant Sci Crop Prot 1(3):1-6

Walker V, Couillerot O, Felten A (2012) Variation of secondary metabolites levels in maize seedling roots induced by inoculation with Azospirillum, Pseudomonas and Glomusconsortium under field conditions. Plant Soil. 356:151-163

Wang YL, Tang JW, Zhang HL, Schroder JL, He YQ (2014) Phosphorus availability and sorption as affected by long-term fertilization. Agron $\mathrm{J}$. 106:1584-1592

Wu Z, Peng Y, Guo L, Li C (2014) Root colonization of encapsulated Klebsiella oxytoca Rs-5 on cotton plants and its promoting growth performance under salinity stress. Eur J Soil Biol. 60: 81 87. https:/doi.org/https://doi. org/10.1016/j.ejsobi.2013.11.008

Wu YN, Feng YL, Pare PW, Chen YL, Xu R, Wu S, Wang SM, Zhao Q, Li HR, Wang YQ, Zhang JL (2016) Beneficial soil microbe promotes seed germination, plant growth and photosynthesis in herbal crop Codonopsis pilosula. Crop Pasture Sci 67(1):91-98

Yadav R, Singh A, Kumar M, Yadav S (2016) Phytochemical analysis and plant growth promoting properties of endophytic fungi isolated from Tulsi and Aloe vera. Int J Agric Stat Sci 12(1):239-248

Yang P, Li X, Wang X, Chen H, Chen F (2007) Proteomic analysis of rice (Oryza sativa) seeds during germination. Proteomics. 7:3358-3368

Zamioudis C, Mastranesti P, Dhonukshe P (2013) Unravelling root developmental programs initiated by beneficial Pseudomonas spp. bacteria. Plant Physiol 162:304-318

\section{Publisher's Note}

Springer Nature remains neutral with regard to jurisdictional claims in published maps and institutional affiliations. 